\title{
Getting it right! Critical Success Factors of BPM in the Public Sector: A Systematic Literature Review
}

\section{Rehan Syed}

Queensland University of Technology

s.abbaszaidi@hdr.qut.edu.au

Wasana Bandara

Queensland University of Technology

\section{Erica French}

Queensland University of Technology

\section{Glenn Stewart}

Queensland University of Technology

\section{Abstract}

The continuously evolving and dynamic social, economic, political environments and public pressures demand governments to deliver effective and efficient public services. In the quest for meeting these demands, governments respond by designing extensive reforms and performance objectives to improve the efficiency and responsiveness of their agencies. Many governments have adopted Business Process Management (BPM) as a strategy to achieve these reforms. However, the successful implementation of BPM initiatives has been a challenging task for agencies responsible for these initiatives, with many projects not reaching completion or not achieving the intended outcomes. This paper reports the results of a systematic literature review on critical success factors (CSFs) related to BPM projects in the public sector. We analysed 31 papers in this review covering both the developed and developing country contexts, sourced from refereed and peer reviewed journals. A quasi-deductive approach was applied for the qualitative data analysis using NVivo 10 software. This resulted in the synthesis and identification of 14 critical success factors of BPM in the public sector, each defined and described in detail with specific attention to the sub-factors mentioned within the literature. Any differences between developed and developing country contexts were sought for, and the observations critically analysed. We propose a series of research questions, designed to support the progression of BPM in the public sector of developed as well as developing countries.

Keywords: Business Process Management; public sector organisations; developed countries; developing countries; critical success factors

\section{Introduction}

Due to rapid changes in global and local socio-economic environments, public sector organisations of both developed and developing countries are faced with many challenges to meet the demands for better public services (Thong, Yap, \& Seah, 2000). The public sector is often characterised by archaic and rigid processes, red-tape and bureaucracies, and is often beset with sudden changes of policies (Hutton, 1996) as a result of elections and changes in the machinery of government.

Organisations adopt Business Process Management (BPM) as an approach and strategy to achieve efficiency, productivity, and improved performance (Davenport, 1993; Trkman, 2010). 
Recognising the value of BPM as an enabler for high performance and increased customer centricity, public sector organisations across the globe have shown keen interest in adopting BPM principles and practices (Alves, Valença, \& Santana, 2014; Kassahun, Molla, \& Sarkar, 2011; Weerakkody, Baire, \& Choudrie, 2006). Dubey and Bansal (2013) referred to BPM as the key solution to effectively handle citizens' demand for better government services. Weerakkody, Janssen, and Dwivedi (2011) observed the growing interest and use of BPM techniques to achieve the required organisational and process related changes for eGovernment. The significance of and need for BPM was recognised by the World Bank (Bhatnagar, 2004) as a key factor for e-Government success in developing countries. Public sector organisations in developing countries in particular, have shown interest in Business Process Management (BPM) since the 1980s (Kassahun \& Molla, 2011; Rajapakse, 2013).

However, the successful implementation of BPM initiatives has been an ongoing challenge. Weerakkody et al. (2006, p. 2) reported that problems related to business processes and ICT are "multiplied in the public sector, where inefficient and bureaucratic business processes and disparate legacy IS/IT systems need to be integrated in an e-Government environment". Gulledge and Sommer (2002, p. 374) argued that government initiatives mainly focus on "plans and performance measures" with limited emphasis and "guidance on how to link the planning objectives to business processes and eventually align the organisational information systems is not included".

There have been numerous reports of failures of these projects, particularly in developing countries (Dada, 2006; Heeks, 2003; Hunter, 2009). Heeks (2003) reported an overall 85\% failure rate. Similarly, Rainford (2006) reported that over $60 \%$ of e-Government initiatives failed to achieve satisfactory results. Heeks and Stanforth $(2007$, p. 165) mentioned that in the last decade, governments in developing countries spent US $\$ 3$ trillion on information technology (IT) projects. Rajapakse (2013) noted that developing countries are in the nascent stages of eGovernment and struggling to perform in line with the developed countries. Yet, despite these struggles and high failure rates, donors and funding bodies continue to fund these projects in developing countries in hope of achieving the Millennium Development Goals (United Nations, 2015).

Critical Success Factors (CSFs) can be used to better systematically manage a program of work as they represent the focal areas that should receive constant and careful attention from management (Dobbins \& Donnelly, 1998). A deep understanding of CSFs enables an organisation to assess its threats, opportunities, weaknesses, and strengths in these dimensions, which is imperative in developing a sound strategy to achieve target project outcomes (Leidecker \& Bruno, 1984).

We acknowledge the prevalence of many CSF studies on BPM that are specific to the private sector context (Buh, Kovačič, \& Indihar Štemberger, 2015; Trkman, 2010). However, a synthesis of the CSFs of public sector BPM initiatives has not been updated since McAdam and Donaghy's paper published in 1999. We argue that a re-assessment and synthesis of the literature is warranted due to major changes in socio-technological environments since 1999. This paper addresses this reassessment. The paper is also driven by the research question: "What are the critical success factors for BPM in public sector organisations?"

In recognition that government agencies in developing countries may have different contexts and challenges to developed countries, we also aim to identify the differences (if any) between the BPM CSFs for developing and developed countries. 
This systematic literature synthesis provides a detailed overview on the current status of research on BPM CSFs in the public sector, and sets a concrete foundation for future research in this domain. The study findings will assist public sector organisations in general to define their strategies for successful BPM transformations, reducing the risk leading to BPM project failure, and can also be used as a springboard for future research for academics and practitioners interested in e-Government and BPM in public sector organisations.

In order to better position this work, the paper proceeds first with a discussion on the potential similarities and differences between public sector versus private sector, and developing versus developed country contexts. Next, the adopted research method is presented together with a simple profiling overview of the selected papers. Then, we present the CSFs identified from the synthesis of literature defining and describing these. Finally, the paper concludes with an overall discussion, making a call for action with a series of prospective research questions to guide further research in this space.

\section{Background}

\subsection{Public versus Private Sector BPM - Differences and Similarities}

Organisational structures, culture, and bureaucratic norms in the public sector are different to private sector organisations (McAdam \& Donaghy, 1999). For example, the 'value creation' concept differs between public and private sector organisations, value creation is the core goal of BPM (Hill, Sinur, Flint, \& Melenovsky, 2006) and in the public sector excludes cost and profitability concerns (Halachmi \& Bovaird, 1997). Tregear and Jenkins (2007) discussed the key differences between public and private sectors across diverse facets (see Table 1, Column 1) and explain how these factors are vital for process oriented management approaches in public sector organisations. Table 1 provides a summarised list of differences discussed by Tregear and Jenkins (2007) and Fettke, Zwicker, and Loos (2014). Tregear and Jenkins (2007, p. 8) stated that "We have proposed a gestalt of differences between public and private sector organizations. These differences must be considered in developing approaches to achieving process-based management in public sector organizations. It is problematic to simply transfer the private sector BPM experience to the establishment and ongoing commitment to GPM".

\begin{tabular}{|l|l|l|}
\hline & Public Sector & Private Sector \\
\hline Mission \& Vision & $\begin{array}{l}\text { Focus is on public interest elements, } \\
\text { societal objectives and outcomes that } \\
\text { can be difficult to quantify. }\end{array}$ & $\begin{array}{l}\text { Focus is on maximising shareholder } \\
\text { return on investment, profitability } \\
\text { and stakeholder value. }\end{array}$ \\
\hline Aim & $\begin{array}{l}\text { Achievement of societal objectives. } \\
\text { Difficult to measure and quantify. } \\
\text { Public task fulfilment. }\end{array}$ & $\begin{array}{l}\text { Achievement of key performance } \\
\text { indicators, production target, } \\
\text { financial targets. Profit maximisation. }\end{array}$ \\
\hline Process Customers & $\begin{array}{l}\text { Complex and diverse set of citizen } \\
\text { groups. Heterogeneous. }\end{array}$ & $\begin{array}{l}\text { Easily identifiable user/consumer } \\
\text { groups. } \\
\text { Mostly heterogeneous. }\end{array}$ \\
\hline $\begin{array}{l}\text { Due process } \\
\text { requirements }\end{array}$ & Fully applicable. & Partially applicable. \\
\hline
\end{tabular}




\begin{tabular}{|c|c|c|}
\hline & Public Sector & Private Sector \\
\hline $\begin{array}{l}\text { Public } \\
\text { Accountability }\end{array}$ & $\begin{array}{l}\text { Comes under the purview and } \\
\text { scrutiny of the parliament, various } \\
\text { authorities and formal bodies } \\
\text { (public). } \\
\text { Risk-taking behaviour is influenced } \\
\text { by public scrutiny. } \\
\text { Risk tolerance depends on election } \\
\text { cycle. }\end{array}$ & $\begin{array}{l}\text { Comes under the purview of the } \\
\text { relevant authorities, legal bodies } \\
\text { (non-public). } \\
\text { Risk-taking behaviour is influenced } \\
\text { by shareholders, corporate boards. } \\
\text { Risk tolerance depends on financial } \\
\text { cycle. }\end{array}$ \\
\hline $\begin{array}{l}\text { Economic } \\
\text { Structure }\end{array}$ & $\begin{array}{l}\text { Monopolistic. Performance } \\
\text { benchmarking is limited. } \\
\text { Political legitimisation (Fettke et al., } \\
\text { 2014). }\end{array}$ & $\begin{array}{l}\text { Variety of economic structures. } \\
\text { Performance benchmarking is } \\
\text { inevitable. Economical market } \\
\text { organization (Fettke et al., 2014). }\end{array}$ \\
\hline $\begin{array}{l}\text { Political } \\
\text { Sensitivity }\end{array}$ & $\begin{array}{l}\text { Highly sensitive, decisions/job } \\
\text { security is subject to public opinion. } \\
\text { Plans/operations are influenced by } \\
\text { the election results. Changes in } \\
\text { political leadership determines the } \\
\text { structure and nature of public } \\
\text { administration. } \\
\text { Governments can be "lobbied". }\end{array}$ & $\begin{array}{l}\text { Partially sensitive, job security is } \\
\text { associated with KPIs. } \\
\text { Plans/Operations are influenced by } \\
\text { the CEO/Board of Directors. } \\
\text { Organisational structure is impacted } \\
\text { by the Corporate strategy. } \\
\text { Organisations play the role of a } \\
\text { lobby. }\end{array}$ \\
\hline Ecosystems & $\begin{array}{l}\text { Whole of Government/e- } \\
\text { Government. Integrated agencies } \\
\text { impacted by jurisdictional challenges } \\
\text { and public scrutiny. Large scale one- } \\
\text { stop operations. }\end{array}$ & $\begin{array}{l}\text { Multi-Level supply chains. } \\
\text { Little impact from jurisdictional } \\
\text { issues. Supported by contacts. }\end{array}$ \\
\hline $\begin{array}{l}\text { Budget Cycle } \\
\text { Complexities }\end{array}$ & $\begin{array}{l}\text { Governments are the largest } \\
\text { spending entity in a country. Budget } \\
\text { process is highly complex, involves } \\
\text { multiple agencies and activities } \\
\text { governed by the law. Budgets comes } \\
\text { under heavy public scrutiny. }\end{array}$ & $\begin{array}{l}\text { Budget process is relatively simple, } \\
\text { involves functional managers. } \\
\text { Approved by the CEO/Board of } \\
\text { directors with little or no public } \\
\text { scrutiny. }\end{array}$ \\
\hline $\begin{array}{l}\text { Information } \\
\text { Exchange }\end{array}$ & $\begin{array}{l}\text { Citizens interact with government on } \\
\text { multiple platforms and for a variety } \\
\text { of citizens' information } \\
\text { requirements. Information needs } \\
\text { may involve multiple government } \\
\text { agencies. } \\
\text { Provision of information is a prime } \\
\text { responsibility. }\end{array}$ & $\begin{array}{l}\text { Customers' interaction with an } \\
\text { organisation is limited to the nature } \\
\text { of transaction. } \\
\text { Little or no focus on provision of } \\
\text { information. }\end{array}$ \\
\hline Regulatory Society & $\begin{array}{l}\text { Governments are the creators and } \\
\text { enforcers of regulations. } \\
\text { Regulations influence the economic } \\
\& \text { social groups. }\end{array}$ & $\begin{array}{l}\text { Organisations are the user \& } \\
\text { complainant of regulations. } \\
\text { Organisations' operations are } \\
\text { influenced by regulations, and } \\
\text { processes are designed to comply } \\
\text { with the regulations. }\end{array}$ \\
\hline $\begin{array}{l}\text { Machinery of } \\
\text { Government } \\
\text { Change }\end{array}$ & $\begin{array}{l}\text { Administrative structure depends on } \\
\text { the political manifesto of the political } \\
\text { regime. Impact of change is complex } \\
\text { and larger due to multi-stakeholder, } \\
\text { multi-agency inter-dependencies. }\end{array}$ & $\begin{array}{l}\text { Administration and structural } \\
\text { changes depend on the changes in } \\
\text { the Boards, and competitive } \\
\text { environment. }\end{array}$ \\
\hline
\end{tabular}




\begin{tabular}{|l|l|l|}
\hline & Public Sector & Private Sector \\
\hline Culture & $\begin{array}{l}\text { Driven by rules \& regulations, } \\
\text { hierarchical decision making } \\
\text { processes, inflexible. Influenced by } \\
\text { political factors. Little attention to } \\
\text { innovation, highly risk-averse, non- } \\
\text { performance oriented, highly } \\
\text { resistant to change. }\end{array}$ & $\begin{array}{l}\text { Based on market factors. Influenced } \\
\text { by customers and social changes. } \\
\text { Rewards and performance oriented, } \\
\text { flexible and less resistant to change. }\end{array}$ \\
\hline
\end{tabular}

Table 1: Differences between public and private sector (constructed based on Tregear and Jenkins, 2007 \& Fettke et al., 2014)

\subsection{Developed versus Developing country context - Differences and Similarities}

Chen, Chen, Huang, and Ching (2006) stated that national e-Government infrastructure, culture, and society factors are different between developed and developing countries and strongly argued that developing countries should design their own e-Government strategies based on their unique factors instead of adopting the strategies of the developed countries. Apart from restrictions on the technological infrastructure and financial capabilities needed for e-Government, developing countries are constrained with competencies and know-how to develop robust strategies for developing and supporting Government improvement initiatives (Chen et al., 2006). Bin Taher, Krotov, and Silva (2015) argued that the models and experience of developed countries cannot be directly applied in developing countries due to various socio-economic and cultural differences. The key differences between developed and developing countries as summarised by Chen et al. $(2006$, p. 27) are presented in Table 2 . These are broad, generic differences and the degree of the existence of these characteristics can vary from country to country within both the developed or developing groups. Nevertheless, it does give a broad and summary synopsis on how the developing and developed countries may differ.

\begin{tabular}{|c|c|c|}
\hline & Developed Countries & Developing Countries \\
\hline $\begin{array}{l}\text { History and } \\
\text { Culture }\end{array}$ & $\begin{array}{l}\text { - Government and economy } \\
\text { developed early, immediately } \\
\text { after independence. } \\
\text { - Economy growing at a constant } \\
\text { rate, productivity increasing, } \\
\text { high standard of living. } \\
\text { - Relatively long history of } \\
\text { democracy and more } \\
\text { transparent government } \\
\text { policies and rules. }\end{array}$ & $\begin{array}{l}\text { Government usually not specifically } \\
\text { defined. } \\
\text { - Economy not growing or increasing in } \\
\text { productivity; low standard of living. } \\
\text { - Relatively short history of democracy and } \\
\text { less transparent government policies and } \\
\text { rules. }\end{array}$ \\
\hline $\begin{array}{l}\text { Technical } \\
\text { Staff }\end{array}$ & $\begin{array}{l}\text { Has a current staff, needs to } \\
\text { increase technical abilities and } \\
\text { hire younger professionals. } \\
\text { - Has outsourcing abilities and } \\
\text { financial resources to } \\
\text { outsource; and staff are able to }\end{array}$ & $\begin{array}{l}\text { Does not have staff with dedicated } \\
\text { technical skills, or has very limited in- } \\
\text { house staff. } \\
\text { - Does not have local outsourcing abilities } \\
\text { and rarely has the financial ability to } \\
\text { outsource; current staff may be unable to } \\
\text { define specific requirements. }\end{array}$ \\
\hline
\end{tabular}




\begin{tabular}{|c|c|c|}
\hline & Developed Countries & Developing Countries \\
\hline & $\begin{array}{l}\text { define requirements for } \\
\text { development. }\end{array}$ & \\
\hline Infrastructure & $\begin{array}{l}\text { - Good current infrastructure. } \\
\text { - High internet access for } \\
\text { employees and citizens. }\end{array}$ & $\begin{array}{l}\text { - Current infrastructure is weak. } \\
\text { - Low internet access for employees and } \\
\text { citizens. }\end{array}$ \\
\hline Citizens & $\begin{array}{l}\text { - High internet access and } \\
\text { computer literacy; still has } \\
\text { digital divide and privacy } \\
\text { issues. } \\
\text { - Relatively more experienced in } \\
\text { democratic systems and more } \\
\text { actively participate in } \\
\text { governmental policy-making } \\
\text { processes. }\end{array}$ & $\begin{array}{l}\text { Low internet access and citizens are } \\
\text { reluctant to trust online services; few } \\
\text { citizens know how to operate computers. } \\
\text { - Relatively less experienced in democratic } \\
\text { systems and less actively participate in } \\
\text { governmental policy-making processes. }\end{array}$ \\
\hline $\begin{array}{l}\text { Government } \\
\text { officers }\end{array}$ & $\begin{array}{l}\text { Decent computer literacy and } \\
\text { dedication of resources; many } \\
\text { do not place e-government at a } \\
\text { high priority. }\end{array}$ & $\begin{array}{l}\text { Low computer literature and dedication of } \\
\text { resources; many do not place e- } \\
\text { government at a high priority due to lack } \\
\text { of knowledge on the issue. }\end{array}$ \\
\hline
\end{tabular}

Table 2: Key differences between developed and developing countries (extracted from Chen et al. (2006, p. 27)

Ahmed and Gregor (2007) argued the relevance of most Information System theories to developing and less-developed country contexts but noted that it was important to identify when these theories were developed and that these theories were mainly tested and often only tested in the developed country context. Similarly, Chen et al. (2006), by referring to the key differences provided in Table 2, argued that e-government strategies that emerged within the context of developed countries cannot be directly applied to developing countries. Zarei, Ghapanchi, and Sattary (2008) instead called for new models, or the re-structuring of existing e-government models designed for developed countries, to suit the context of the developing countries due to differences in the technical, cultural, social, political and economic infrastructures.

BPM efforts in developing countries often differ widely for various reasons. First, in developing countries the limited access to and availability of BPM expertise restrict the ability to enjoy full benefits of process efficiencies (Bandara, Syed, Kapurubandra, \& Rupasinghe, 2012; Huang \& Palvia, 2001). Second, most developing countries face different levels of a digital divide and information poverty due to considerably underdeveloped technology infrastructure and technical know-how (Chen et al., 2006; Heeks, 2008b; United Nations, 2016; Walsham, Robey, \& Sahay, 2007; Walsham \& Sahay, 2006; World Bank, 2014). Third, and perhaps most important, with the exception of a few, most developing countries face volatile political, social, and economic macro-environments that may adversely affect the implementation and sustainability of process improvement initiatives (Walsham \& Sahay, 2006; Weerakkody, El-Haddadeh, \& Al-Shafi, 2011). 
Therefore, it can be deduced that BPM CSFs in developing countries may have some unique contextual differences to those seen in developed contexts. The next section discusses the systematic literature review methodology to identify contextual differences in BPM CSFs.

\section{Approach and Methodology}

A number of researchers offer advice on literature reviews. Bandara, Furtmuller, Gorbacheva, Miskon, and Beekhuyzen (2015) provide a detailed synthesis and harmonisation of existing literature review guidelines, and describe an end-to-end approach with tool support to assist with the rigour, and transparency of literature reviews. Webster and Watson (2002, p. xix) refer to a literature review as an important component of all scholarly efforts and explained how a review should "identify critical knowledge gaps" while Alvesson and Sandberg (2013) describe the different ways gap-spotting is done. Though they critique gap-spotting as a sole approach to derive research problems, they conclude that gap-spotting is the most popular way of identifying and justifying research problems at present. Müller-Bloch and Kranz (2015) provide guidelines to identify research gaps in literature reviews. This paper uses the Bandara et al., (2015) guidelines to conduct a review, and the Alvesson and Sandberg's (2013) gapspotting classification together with the Muller-Bloch and Kranz (2015) guidelines for identifying future areas of research.

We sought to build upon the existing work of McAdam and Donaghy (1999) on public sector BPM CSFs as the initial framework for analysis. The scope of our literature search extended from post McAdam and Donaghy (1999) till December 2014. Figure 1 illustrates the applied phases of the systematic literature review, and these phases are described further below. 


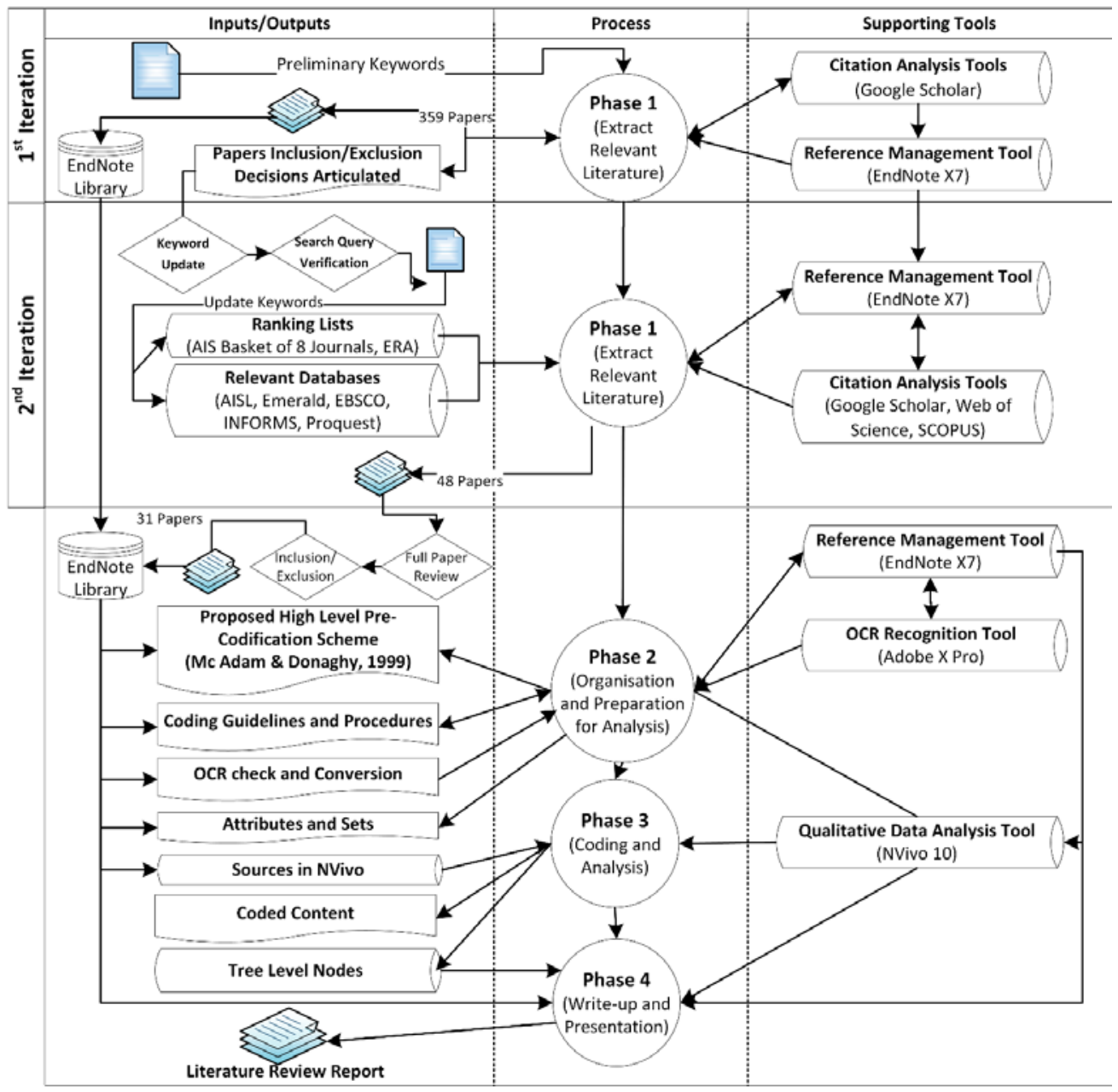

Figure 1. Data Collection and Analysis Approach (adopted from Bandara et al., 2015)

\subsection{Phase 1: Searching and Extracting the Relevant Pool of Papers}

The topic of this study falls broadly into the disciplines of Management and Information Systems (IS). Therefore, both these domains were selected as the primary fields for literature search. The selection criteria used to ensure the relevance of articles to the research goals and scope is illustrated in Table 3.

\begin{tabular}{|c|l|}
\hline Rule \# & Criterion Description \\
\hline $\mathbf{1}$ & The articles should be related to the public sector context. \\
\hline $\mathbf{2}$ & $\begin{array}{l}\text { The articles should be about BPM or other very closely related topics pertaining to } \\
\text { process-centric improvements (such as Business Process Re-engineering, Business Process } \\
\text { Improvement, Lean Six sigma etc.) in public sector organisations. }\end{array}$ \\
\hline $\mathbf{3}$ & $\begin{array}{l}\text { The articles related to the external, citizen perspective (i.e. adoption of e-Government } \\
\text { services, digital divide, policy frameworks etc.) were not considered relevant to the scope. }\end{array}$ \\
\hline $\mathbf{4}$ & $\begin{array}{l}\text { The articles focusing on technology frameworks/architectures, data standards, software } \\
\text { development were not considered relevant to the scope as these areas represent specific } \\
\text { technical aspects of design and development of e-Government software applications. }\end{array}$ \\
\hline $\mathbf{5}$ & \begin{tabular}{l} 
Only peer-reviewed full articles that are in English were taken into consideration. \\
\hline
\end{tabular}
\end{tabular}

Table 3: Criteria Used for Literature Search 
The search for literature was performed in 2 iterations. In the first iteration, a preliminary search was conducted via Google Scholar using search strings ["business process management" AND "critical success factors" AND "public sector" NOT erp NOT software]. The Boolean term 'NOT' was added in adherence to rule 4 above after early search results needed to be constrained to enhance relevance derived from keywords listed under '1st iteration' in Table 4 .

\begin{tabular}{|l|l|l|l|l|}
\hline \multicolumn{1}{|c|}{$\mathbf{1}^{\text {st } \text { Iteration }}$} & \multicolumn{3}{|c|}{$2^{\text {nd }}$ Iteration } \\
\hline \multicolumn{1}{|c|}{ Keywords } & \multicolumn{3}{|c|}{ Keywords + Synonyms \& other related terms } \\
\hline Public Sector & Government & State & & \\
\hline $\begin{array}{l}\text { Business } \\
\text { Process } \\
\text { Management }\end{array}$ & e-Government & e-Transformation & $\begin{array}{l}\text { Organisational } \\
\text { Transformation }\end{array}$ & \\
\cline { 2 - 5 } & $\begin{array}{l}\text { Business Process } \\
\text { Reengineering }\end{array}$ & $\begin{array}{l}\text { Business Process } \\
\text { Change }\end{array}$ & $\begin{array}{l}\text { Business Process } \\
\text { Improvement }\end{array}$ & Change \\
\hline $\begin{array}{l}\text { Success } \\
\text { Factors }\end{array}$ & $\begin{array}{l}\text { Critical Success } \\
\text { Factors }\end{array}$ & $\begin{array}{l}\text { Key Success } \\
\text { Factors }\end{array}$ & Acceptance & Adoption \\
\hline
\end{tabular}

Table 4: Keywords and Synonyms used for Literature Search

In the second iteration, literature was initially searched using the 'Basket of Eight Journals in IS' (see, https://aisnet.org/?SeniorScholarBasket). However, our search found no articles related to the public sector. As a result, the search was widened through the EBSCO, Emerald Insight, ABI/INFORM, IEEEXplore, ACM, Science Direct, and ProQuest databases. The articles were extracted in EndNote and checked for duplication. Forty-three (43) articles that fitted the selection criteria were selected for analysis. Finally, SCOPUS and Web of Science (WoS) were utilised for forward and backward searching. Through this mechanism, another 5 new articles were included, resulting in a total of 48 relevant articles.

\subsection{Phase 2: Preparation for the Analysis}

Next, all 48 articles were fully read to analyse and confirm the content relevancy and to further refine the dataset. It was found that the content of a few articles did not reflect their abstracts, titles and keywords. As an outcome, only Thirty-one (31) articles qualified for the detailed analysis.

The selected papers were first checked for text-recognition and converted using Adobe OCR function to be readable in NVivo, then exported to NVivo (from EndNote) following the guidelines of Bandara et al. (2015). All papers were stored as documents with attributes (such as case study, literature review, survey, and publication outlet) maintained. Papers were imported as 'Author-Year' format to facilitate the traceability of the papers in support of the write-up phase (Bandara et al., 2015). A coding rulebook (following DeCuir-Gunby, Marshall, $\&$ McCulloch, 2011) was developed and maintained to guide the coding process.

\subsection{Phase 3 \& 4: The Data Analysis Procedures and Literature Profiling Outcomes}

The literature analysis took place in multiple stages. First the literature was profiled (see results below) to obtain an overview on the current status of the existing literature. A quasi- 
deductive qualitative data analysis approach following Bandara et al. (2015) was applied for the detailed analysis. McAdam and Donaghy (1999)'s results were used as an a priori coding framework while allowing new themes to emerge from the data. The analysis of gaps and opportunities for future research was conducted as part of the overall literature analysis, following insights from Alvesson and Sandberg (2013) (to identify different types of gaps and opportunities) and the guidelines of Muller-Bloch and Kranz (2015).

\subsection{Profile of the Reviewed Articles}

Profiling of literature in a review-based analysis can provide useful insights about the overall status of research, assist with quality assurance (in support of selection bias) and provide input to future research agendas (Gaffar, Deshpande, Bandara, \& Mathiesen, 2015). An analysis of the key outlets and geographical distribution of the studies are presented here for this purpose; the Business Process Management Journal (7 articles), the International Journal of Electronic Government Research (5 articles) and the Journal of Enterprise Information Management (3 articles) were three key publication outlets. The rest of the articles were distributed amongst other journals and sources. Figure 2 illustrates the geographical spread of research on BPM in the public sector. The blue dots represent the studies conducted in developed countries, whereas the red dots represent developing countries. Among the selected Thirty-one (31) articles, 8 articles provided the developing country's perspective.

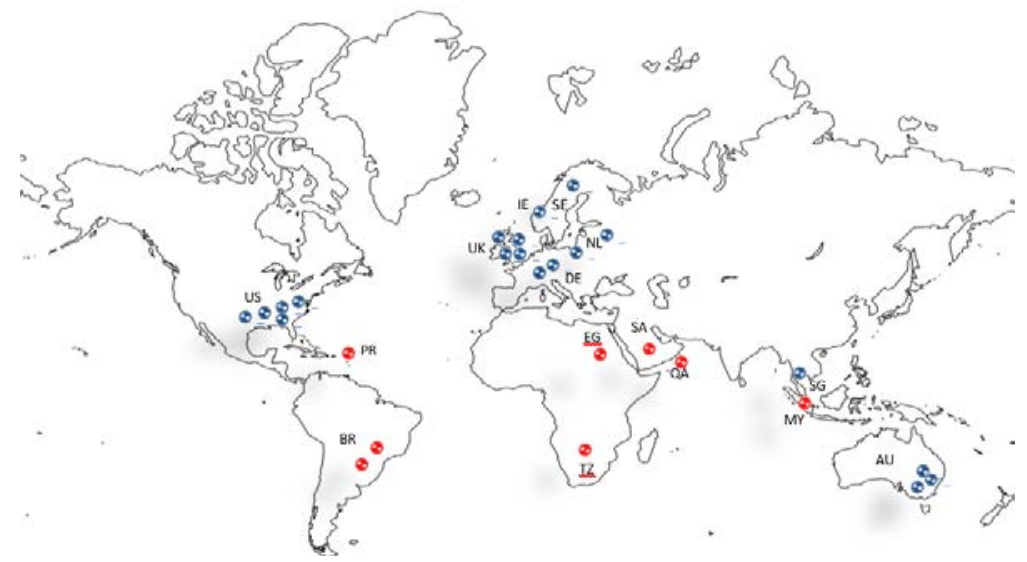

Figure 2: Articles by Geography

\section{Study Findings: The Critical Success Factors of BPM}

The above approach resulted in Fourteen (14) CSFs, all are first clearly defined and then explained in further detail below.

\subsection{Identifying and Defining the Critical Success Factors}

The definitions for each of the Fourteen (14) factors (adopted from the literature) as used in this study are presented in Table 5 in the order of most discussed to least discussed. When deriving these definitions, any direct or indirect (implied) mentioning of each factor, together with the definitions and any additional insights the papers provided were coded, and checked by a second coder. Furthermore, additional aspects that contributed towards a factor were also captured to enable a better understanding on what each factor was formed on. 


\begin{tabular}{|c|c|c|}
\hline CSF & Example definitions gathered from the literature & Adopted Definition \\
\hline 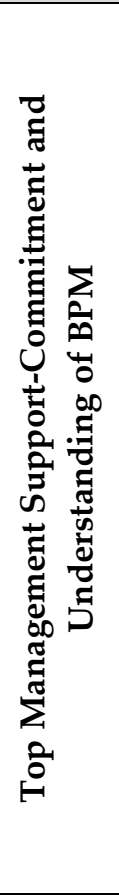 & $\begin{array}{l}\text { "willingness of top management to accept and } \\
\text { implement the re-engineering team's } \\
\text { recommendations" (McAdam and Donaghy, 1999, } \\
\text { p.44); a proactive push to leverage potential } \\
\text { opportunities enabled by change agents, ensured } \\
\text { the funding to support the project, driven by local } \\
\text { management with a strong business case; the } \\
\text { delineation of a specific plan of action and then } \\
\text { motivation of the entire organisation". (Kennedy } \\
\text { et al, 201); "the existence of a single person within the } \\
\text { organisation who is committed to introducing the } \\
\text { innovative IT initiative to the organisation"(Kamal, } \\
\text { 2006, p.213); " Clear leadership is essential to make } \\
\text { this effort work" (Al-Kibsi, et al. 2001, p.69); "to be } \\
\text { effective in implementing e-government projects, the } \\
\text { CIO should occupy a position in a senior central } \\
\text { agency of government with an enterprise-wide view of } \\
\text { government operations or budget." (Marilu, 2012, } \\
\text { p.4). }\end{array}$ & $\begin{array}{l}\text { Senior management's active } \\
\text { involvement in the project, with } \\
\text { provisions of resources and } \\
\text { funding, motivation, acceptance of } \\
\text { risks, perseverance, and strong } \\
\text { leadership qualities. }\end{array}$ \\
\hline 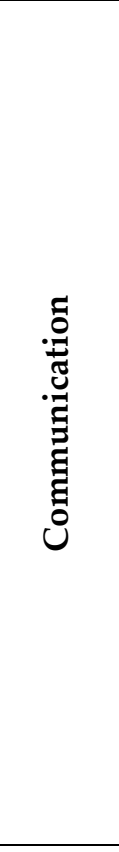 & $\begin{array}{l}\text { "to reduce the Resistance to change it is necessary to } \\
\text { develop internal and external communication } \\
\text { strategies of the BPM initiative. These strategies shall } \\
\text { disseminate information about the BPM key concepts, } \\
\text { while communicating the results of the initiative" } \\
\text { (Alves, et al., 2014, p.285); "all stakeholders - users, } \\
\text { suppliers, delivery partners elsewhere in the public, } \\
\text { private and voluntary sector, politicians, the media etc. } \\
\text { have a clear understanding of the programme and how } \\
\text { they can engage with it." (Borras, 2012, p.46); } \\
\text { "Communicate with stakeholders about the system: sell } \\
\text { the true benefits and address the true negative aspects" } \\
\text { (Heeks, 2003, p.13); "consolidation and } \\
\text { communication of IT-governance-related policies and } \\
\text { guidelines. This can enhance the control, changes and } \\
\text { enforcement of IT-governance-related policies and } \\
\text { guidelines for performing IT-enabled functions." } \\
\text { (Nfuka \& Rusu, 2011, p.1436). }\end{array}$ & $\begin{array}{l}\text { Organisational strategies, channels, } \\
\text { and methods to enable on-time, } \\
\text { clear, and accurate exchange of } \\
\text { relevant information amongst the } \\
\text { stakeholders. }\end{array}$ \\
\hline 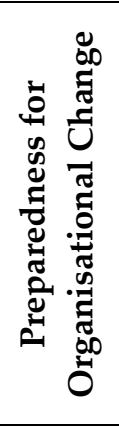 & $\begin{array}{l}\text { "how a manager or leader manages the potential } \\
\text { impact of change to make people accept it in order to } \\
\text { implement change" (Hartini et al., 2007, p.458); } \\
\text { "breaking the organisational status quo and } \\
\text { introducing new practices, new values and new } \\
\text { structures" (McAdam \& Donaghy, 1999, p.46); "the } \\
\text { influence of the social environment on the employees' } \\
\text { perception of the transformation" (Meier, Ben, \& } \\
\text { Schuppan, 2013, p.320). }\end{array}$ & $\begin{array}{l}\text { Monitoring, measurement, and } \\
\text { mitigation strategies to effectively } \\
\text { prepare and overcome potential } \\
\text { impact of changes in internal and } \\
\text { external environments on people } \\
\text { and processes in an organisation. }\end{array}$ \\
\hline
\end{tabular}




\begin{tabular}{|c|c|c|}
\hline CSF & Example definitions gathered from the literature & Adopted Definition \\
\hline 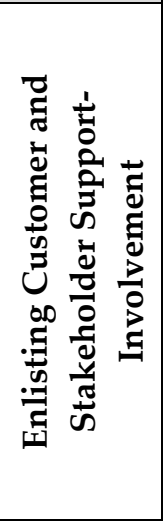 & $\begin{array}{l}\text { "customer focus is now emphasised more within the } \\
\text { public sector, and customer friendliness and } \\
\text { simplification of procedures is the imperative of the } \\
\text { administration, in keeping with the stated aim of the } \\
\text { organisation." (Kennedy, et al., 2012, p.19); "need } \\
\text { for a greater awareness of the customers of public } \\
\text { services" (McAdam \& Donaghy, 1999, p.47); } \\
\text { "harnessing the full power of e-government requires } \\
\text { reorganizing departmental processes around the needs } \\
\text { of citizens and businesses" (Al-Kibsi, et al., 2001, } \\
\text { p.69). }\end{array}$ & $\begin{array}{l}\text { A systematic approach } \\
\text { incorporating active stakeholders } \\
\text { and customer participation to } \\
\text { continuously monitor and identify } \\
\text { system and service needs for } \\
\text { process improvement. }\end{array}$ \\
\hline 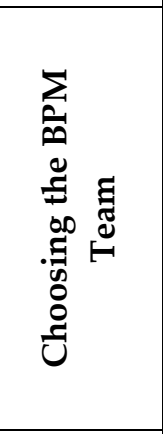 & $\begin{array}{l}\text { A core BPR group together with cross-functional } \\
\text { specialist groups; experienced in variety of } \\
\text { techniques. (Al-Mashari \& Zairi, 1999; McAdam \& } \\
\text { Donaghy, 1999); "a cross-functional steering } \\
\text { committee was created and the team teased out at a } \\
\text { very early stage the essential enablers to the successful } \\
\text { introduction of new technologies including issues } \\
\text { related to people and process" (Kennedy, et al., 2012, } \\
\text { p.16). }\end{array}$ & $\begin{array}{l}\text { A coherent cross-functional unit } \\
\text { skilled with relevant technical and } \\
\text { management techniques to lead the } \\
\text { BPM implementation in an } \\
\text { organisation. }\end{array}$ \\
\hline 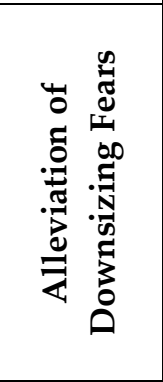 & $\begin{array}{l}\text { "Maintenance of job security" (McAdam \& } \\
\text { Donaghy, 1999, p.42); "an attempt to maintain the } \\
\text { status quo, is commonly understood to be almost } \\
\text { universal in change processes" (Marilu, 2012, p.10); } \\
\text { "BPM pilot projects shall increase Managers fearing } \\
\text { power loss. It means that managers may understand } \\
\text { that these projects are affecting their own areas and } \\
\text { threatening their control" (Alves, et al., 2014, p.282) }\end{array}$ & $\begin{array}{l}\text { Employees Resistance to change } \\
\text { from the effects of actual or } \\
\text { expected outcomes related with } \\
\text { BPM and IT implementation. }\end{array}$ \\
\hline 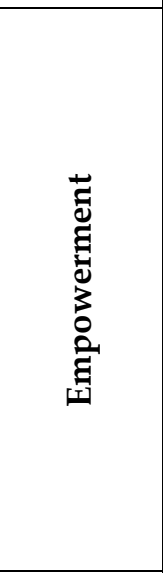 & $\begin{array}{l}\text { Involvement of staff, outside the reengineering } \\
\text { team in the BPR exercise, incorporating their } \\
\text { views and opinions (McAdam \& Donaghy, 1999); } \\
\text { "organisational structure should enable BPR in terms } \\
\text { of its encouraging creativity and innovativeness in the } \\
\text { organisation, therefore the need for less bureaucracy, } \\
\text { and more participation and empowerment in the } \\
\text { organisation" (Hartini, et al., 2007, p.459); "Senior } \\
\text { management interdepartmental coordinating } \\
\text { committees with a mandate and reporting } \\
\text { accountability to the agency head are necessary" } \\
\text { (Marilu, 2012, p.4). }\end{array}$ & $\begin{array}{l}\text { A managerial process to ensure } \\
\text { provision of required delegation of } \\
\text { authority, responsibility and } \\
\text { accountability to the core BPM } \\
\text { team. }\end{array}$ \\
\hline 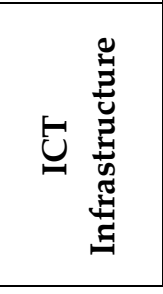 & $\begin{array}{l}\text { "the systems needed for effective communication, and } \\
\text { whether organisation's personnel perceive information } \\
\text { sharing and information flow using those systems as } \\
\text { being difficult to understand and use" (Kamal, 2006, } \\
\text { p.210). }\end{array}$ & $\begin{array}{l}\text { Physical hardware, system } \\
\text { architectures, software systems, } \\
\text { technology policies and standards, } \\
\text { and management processes } \\
\text { required for seamless collection } \\
\text { and dissemination of information. }\end{array}$ \\
\hline
\end{tabular}




\begin{tabular}{|c|c|c|}
\hline CSF & Example definitions gathered from the literature & Adopted Definition \\
\hline 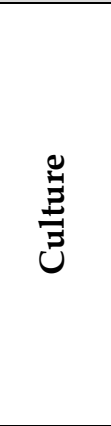 & $\begin{array}{l}\text { "a well-established culture of teamwork would make it } \\
\text { easier for the organisation to achieve its goals" } \\
\text { (Hartini, Arthur, \& Zairi, 2007, p.457); "Revision of } \\
\text { reward systems, communication, empowerment, people } \\
\text { involvement, training and education, creating a } \\
\text { culture for change, and stimulating receptivity of the } \\
\text { organisation to change are the most important factors } \\
\text { related to change management and culture" (Al- } \\
\text { Mashari and Zairi, 1999, p.88). }\end{array}$ & $\begin{array}{l}\text { Organisational core value system, } \\
\text { shared beliefs and norms that } \\
\text { differentiate an organisation in an } \\
\text { industry. }\end{array}$ \\
\hline 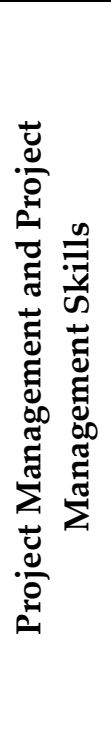 & $\begin{array}{l}\text { "adequate plan execution as well as a flexible and } \\
\text { adaptive methodology represent further important } \\
\text { success factors as pertaining to BPR project } \\
\text { management" (Jurisch, 2012, p.2605); "the process by } \\
\text { which projects are defined, planned, monitored and } \\
\text { controlled to achieve the project objectives of timely } \\
\text { delivery, adherence to budget, conformance to } \\
\text { specifications and stakeholder satisfaction. It involves } \\
\text { the management of an endeavor, with defined } \\
\text { beginning and end periods, undertaken with tools and } \\
\text { techniques, to create a unique product or service." } \\
\text { (Kwamena, 2012, p.60); "In terms of project } \\
\text { management, prioritisation of deliverables will ensure } \\
\text { that the most strategically significant services are } \\
\text { managed and delivered appropriately" (Weerakkody, } \\
\text { El-Haddadeh, \& Al-Shafi, 2011, p.176) }\end{array}$ & $\begin{array}{l}\text { A robust project management } \\
\text { methodology and development of } \\
\text { leadership, interpersonal, planning, } \\
\text { financial, communication, } \\
\text { negotiation and change } \\
\text { management skills for staff } \\
\text { involved in BPM projects. }\end{array}$ \\
\hline 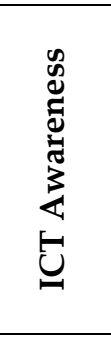 & $\begin{array}{l}\text { "appropriate training and development of new skills } \\
\text { among staff" (Jurisch, et al., 2012, p.2606); proper } \\
\text { training to develop adequate skills for employees } \\
\text { to enable them to perform the assigned tasks and } \\
\text { responsibilities (Hartini, et al., 2007; Heeks 2003). }\end{array}$ & $\begin{array}{l}\text { Training and development } \\
\text { initiatives to develop technical } \\
\text { competence of public sector } \\
\text { employees in order to capitalise on } \\
\text { potential use of Information } \\
\text { Communication Technology } \\
\text { systems. }\end{array}$ \\
\hline 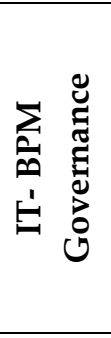 & $\begin{array}{l}\text { "a reference framework to guide organizational units to } \\
\text { ensure responsibility and accountability" (Alves, et } \\
\text { al., 2014, p.274). systematic planning that includes } \\
\text { the definition of specific roles and responsibilities, the } \\
\text { description of policies and methodologies, and the } \\
\text { selection of process-oriented software tools (Valenca, } \\
\text { Alves, Santana, de Oliveira, \& Santos, 2013, p. 2) }\end{array}$ & $\begin{array}{l}\text { Management practices and policies, } \\
\text { span of management, and standard } \\
\text { operating procedures to guide ICT } \\
\text { operations and BPM projects in a } \\
\text { government organisation. }\end{array}$ \\
\hline
\end{tabular}




\begin{tabular}{|c|c|c|}
\hline CSF & Example definitions gathered from the literature & Adopted Definition \\
\hline 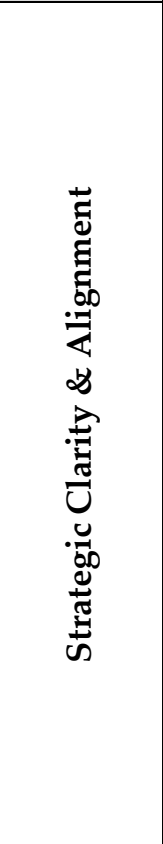 & $\begin{array}{l}\text { "all-of-government view, establishing a clear vision, a } \\
\text { strong business case, and a result-focused strategy" } \\
\text { (Borras, 2012, p.45); "interrelation between } \\
\text { compatibility of the IT system with the organisational } \\
\text { need; organisational compatibility, which that can be } \\
\text { thought of as the organisational fit of the system } \\
\text { required for effective information sharing among } \\
\text { different departments." (Kamal, 2011, p.211); "for e- } \\
\text { government initiatives to accomplish the stated goals, } \\
\text { their strategic goals should be aligned with the } \\
\text { government agency's mission, strategic goals and } \\
\text { business processes" (Kwamena, 2012, p.46); "e- } \\
\text { Government initiatives will be most effective and the } \\
\text { impact of ICT is most powerful when e-Government is } \\
\text { clearly defined as part of a broader public sector reform } \\
\text { initiative" (Marilu, 2012, p.4); "alignment of IT with } \\
\text { business strategy and enabling IT structures" (Nfuka } \\
\text { \& Rusu, 2011, p.1436). }\end{array}$ & $\begin{array}{l}\text { ICT strategic vision, mission, goals, } \\
\text { and operational plans of a public } \\
\text { sector organisation that are aligned } \\
\text { with the political and social aims } \\
\text { established by the government } \\
\text { leadership. }\end{array}$ \\
\hline 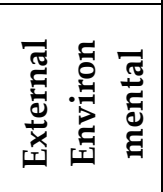 & $\begin{array}{l}\text { "external forces or influences refers to the impact that } \\
\text { external associations exercise on the organisation" } \\
\text { (Kamal, 2006, p.214) }\end{array}$ & $\begin{array}{l}\text { Global and local political, social, } \\
\text { and economic macro factors that } \\
\text { influence a public sector } \\
\text { transformation endeavour. }\end{array}$ \\
\hline
\end{tabular}

Table 5: Summary of Critical Success Factor Definitions

An NVivo Matrix Query (see Bazeley, 2007 for further details ) was used to provide the summary synopsis (see Table 6 below), which illustrates the extent to which each critical success factor was derived and supported from the literature review (they are presented in order of most to least supported within the two categories of a priori and new factors). The numbers in each cell illustrate the frequency (number of separate coding references) a factor was discussed under each evidence-category which were Definitions (A), Direct Supporting Observations (B), Indirect Support Observations (C) and Other Additional Insights (D). Note columns in the table denoted by the classification ' $A$ ', ' $B$ ', ' $C$ ' and ' $\mathrm{D}$ ' for each paper which is presented in rows, in alphabetical order by first author. 




Table 6: Cross Tabulation Matrix 


\section{A Detailed Review of the Critical Success Factors}

The following section provides a discussion around each factor (in order of most prevalent to least prevalent), describing how the literature discussed the factor. Sub-factors pertaining to each factor were extracted from the literature analysis in order to provide a deeper level of understanding of each factor. Prospective research questions to shape future research were derived based on gaps and opportunities observed from this analysis.

\subsection{Top Management Support and Understanding of BPM}

Top management support was one of the main factors mentioned for a successful BPM implementation. Key attributes of top management support entail the provisioning of project funding, motivating staff and being change agents (Kennedy, Joseph, \& Carol, 2012), and strategic alignment (Alves et al., 2014). A different perspective was presented by Doebeli, Fisher, Gapp, and Sanzogni (2011) that includes corporate governance, leadership, bureaucracy and a formal structure within an organisation as the key aspects of top management support. Alghamdi, Goodwin, and Rampersad (2014) also reported that corporate governance and the management's ability to involve the right people were two key factors behind the success of public sector transformation projects. Ravesteyn and Batenburg (2010) gave strong emphasis on a top-down approach for BPM projects in an organisation.

Leadership is another key factor discussed within the context of top management support. AlKibsi, de Boer, Mourshed, and Rea (2001) identified a lack of leadership as a restricting factor for online integration and the need for it in redesigning processes. Kamal (2006) further stressed the need for a committed champion to introduce novel IT endeavours. From a developing country's perspective, Alghamdi et al. (2014) emphasised the creation of leadership steering committees while Nfuka and Rusu (2011) discussed the importance of articulating a vision for the IT role by the Chief Information Officer (CIO) or equivalent in public sector projects. Streib and Navarro (2008) recommended the need for training and development in the public sector to develop much needed knowledge, skills, and leadership abilities. Along similar lines, Axelsson, Melin, and Söderström (2011) linked leadership skills with successful IT-enabled transformation and risk management. Furthermore, the crucial role of leadership in e-Government projects to develop team cohesion was reported by Marilu (2012) as well as. These sub-factors that seem to describe what was meant by or expected of top management support are documented in Table 7. 


\begin{tabular}{|c|c|c|c|c|c|c|c|c|c|c|}
\hline$\left({ }^{*}\right)$ represents developing countries & 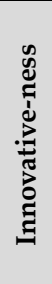 & 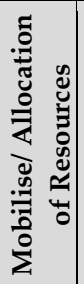 & 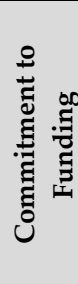 & 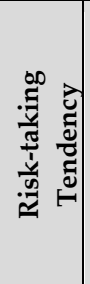 & 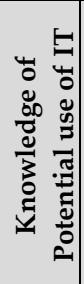 & 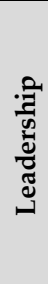 & 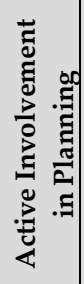 & 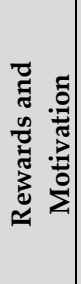 & 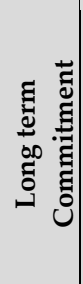 & 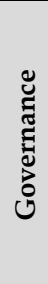 \\
\hline${ }^{*}$ Alghamdi et al. (2014) & & & & & & $\sqrt{ }$ & & & & $\sqrt{ }$ \\
\hline *Alves et al. (2014) & & & $\sqrt{ }$ & & & $\sqrt{ }$ & & $\sqrt{ }$ & & \\
\hline${ }^{*}$ Hartini, Francis, and Zairi (2007) & & & $\sqrt{ }$ & & & & & & & $\sqrt{ }$ \\
\hline *Hisham, Christopher, and Hatem (2012) & & & & & & & $\sqrt{ }$ & & & \\
\hline${ }^{*}$ Nfuka and Rusu (2011) & & $\sqrt{ }$ & & & & & $\sqrt{ }$ & & & \\
\hline *Weerakkody, El-Haddadeh, and Al-Shafi (2011) & & $\sqrt{ }$ & $\sqrt{ }$ & $\sqrt{ }$ & & & & & & \\
\hline Al-Kibsi et al. (2001) & & & & & & $\sqrt{ }$ & & & & \\
\hline Axelsson et al. (2011) & & & & $\sqrt{ }$ & & $\sqrt{ }$ & & & $\sqrt{ }$ & \\
\hline Borman and Janssen (2012) & & & & & $\sqrt{ }$ & & & & & \\
\hline Doebeli et al. (2011) & & & & & & $\sqrt{ }$ & & & & \\
\hline Jurisch, Ikas, Palka, Wolf, and Krcmar (2012) & & $\sqrt{ }$ & $\sqrt{ }$ & & & & $\sqrt{ }$ & & & \\
\hline Kamal (2006) & $\sqrt{ }$ & $\sqrt{ }$ & $\sqrt{ }$ & $\sqrt{ }$ & $\sqrt{ }$ & & & & & \\
\hline Kennedy et al. (2012) & & & & & & $\sqrt{ }$ & $\sqrt{ }$ & & $\sqrt{ }$ & \\
\hline Kwamena (2012) & & & & & & $\sqrt{ }$ & & & & \\
\hline Marilu (2012) & & & & & & & & & & $\sqrt{ }$ \\
\hline Tan, Cater-Steel, and Toleman (2009) & & & & & & $\sqrt{ }$ & & & & $\sqrt{ }$ \\
\hline
\end{tabular}

Table 7: Summary of Attributes Underpinning Top Management Support

When comparing the developed and developing country contexts (greyed rows used in Table 7) it was revealed that the 'innovativeness', 'knowledge of potential use of IT', and 'long term commitment' factors were not discussed in the literature related to developing countries. In contrast, 'rewards and motivation' was a distinctive factor mentioned in one study on developing countries. Research into top management support for BPM in the public sector is limited. Although leadership is identified as a key factor for BPM project success under top management support, the studies on the style, nature and attributes of leadership that contribute to BPM success are scarce (also stated in Syed, Bandara, French, \& Stewart, 2016). Thus, we propose further research on the following: 'How can top management support within public sector BPM initiatives be conceptualised?'; 'How does leadership contribute to the success and sustainability of BPM in the public sector?' Furthermore, research on: 'How to build leadership capabilities on process-centric innovation in public sector?', and 'How to obtain sustained long term top management commitment for BPM in public sector?' is warranted.

\subsection{Communication}

Communication of BPM strategies is vital to enable on-time, clear, and accurate exchanges of relevant information among stakeholders (Chong \& Rosemann, 2010). Alves et al. (2014, p. 283) discussed the need for communication as a strategy to overcome resistance to change, introduce the BPM approach, and to communicate the outcomes and achievements of the BPM project. The impact and effectiveness of communication on BPM project success has been widely acknowledged (Alves et al., 2014; Borman \& Janssen, 2012; Kwamena, 2012; Marilu, 
2012; Nfuka \& Rusu, 2011; Ravesteyn \& Batenburg, 2010). Studies by Heeks (2003) and Borras (2012) emphasised the provision of clear BPM project objectives for effective stakeholder involvement. Hartini, Francis, and Zairi (2007) posited cross-functional integration and teamwork as key determinants of communication. Meier, Ben, and Schuppan (2013) advocated the quality and sufficiency of information for controlling and enforcing ITGovernance policies. It is noted that the communication strategy for BPM can be effectively used for team collaboration and coordination as well as for stakeholders engaged with the project. Communication for collaboration and coordination is also referred to as an important technique to handle resistance to change. The sub-factors that seem to further describe communication (as a CSF of BPM) are documented in Table 8.

\begin{tabular}{|c|c|c|c|c|c|}
\hline (*) represents developing countries & 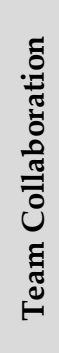 & 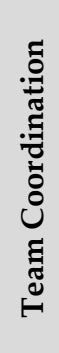 & 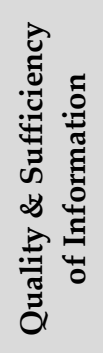 & 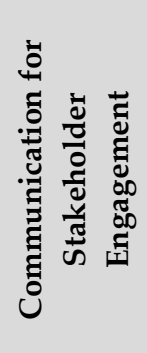 & 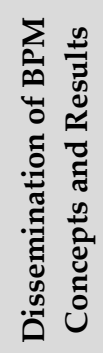 \\
\hline *Alves et al. (2014) & & & & & $\sqrt{ }$ \\
\hline *Hartini et al. (2007) & $\sqrt{ }$ & $\sqrt{ }$ & & & \\
\hline${ }^{*}$ Nfuka and Rusu (2011) & $\sqrt{ }$ & & & & \\
\hline Al-Mashari and Zairi (1999) & & & & $\sqrt{ }$ & \\
\hline Borman and Janssen (2012) & $\sqrt{ }$ & $\sqrt{ }$ & & $\sqrt{ }$ & \\
\hline Borras (2012) & & & & $\sqrt{ }$ & \\
\hline Heeks (2003) & & & & $\sqrt{ }$ & \\
\hline Kwamena (2012) & & & & $\sqrt{ }$ & \\
\hline Meier, Ben, and Schuppan (2013) & & & $\sqrt{ }$ & & \\
\hline
\end{tabular}

Table 8: Summary of Communication Aspects in BPM

The three articles covering developing countries did not mention 'quality and sufficiency of information', or 'stakeholder engagement' in the context of communication. The literature on developed countries emphasised the value of communication for better stakeholder engagement. These differences may be attributed to the different socio-cultural issues (Chen et al., 2006) between the two groups. Despite many discussions (30+ coding references, as shown in Table 6) indicating the importance of communication for BPM success, important details such as 'What are the essential elements of a public sector BPM communication plan' are scarce. The importance of communication for effective stakeholder engagement in public sector BPM efforts, though mentioned widely, could be further studied - especially within the developing country context, where "BPM stakeholders", including the non-traditional stakeholder groups (such as the various social networks that have the capacity to make a difference), need to be better understood to design and test innovative engagement techniques. Hence, research is warranted on 'Who are public sector BPM stakeholders and what are their potential impacts on BPM efforts?' 


\subsection{Preparedness for Organisational Change}

Sound change management practices are important to effectively prepare and overcome the potential impact of changes (coming from internal and external environments) on people and processes. McAdam and Donaghy (1999) recognised rigid structures in government organisations as the main hindrance for BPM related change. Hartini et al. (2007) construes change management as a strategy to manage the potential impact and people acceptance to implement change. Kennedy et al. (2012) linked the causes of change with resource challenges. Alves et al. (2014) posited that BPM activities performed in parallel with routine work can lead to resistance in the public sector. Kwamena (2012) argued that the ability to adopt rapid technological change is restricted by the manner in which public administrators function. Meier et al. (2013) reported positive association between social influences and change where staff were amenable to change when the initiative was supported by managers and colleagues. A few studies discussed the use of rewards and benefits (Heeks, 2003) and staff involvement to handle resistance to change in public organisations (Alghamdi et al., 2014). Training and development programs to build team skills were advocated by Jurisch, Ikas, Palka, Wolf, and Krcmar (2012), whereas the development of internal and external communication strategies was emphasised by Alves et al. (2014). Table 9 depicts the change management sub-factors as discussed in the literature.

\begin{tabular}{|c|c|c|c|c|c|c|c|c|c|c|}
\hline $\begin{array}{l}\text { (*) represents developing } \\
\text { countries }\end{array}$ & 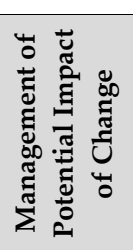 & 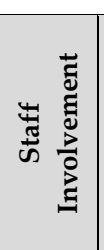 & 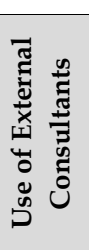 & 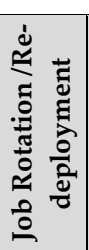 & 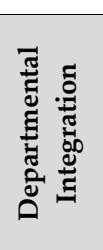 & $\begin{array}{l}\bar{\pi} \\
\text {.ूँ } \\
\text { के }\end{array}$ & 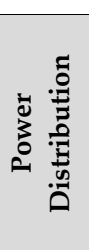 & 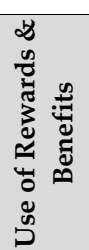 & 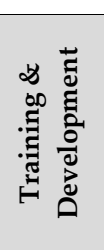 & 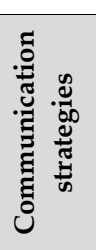 \\
\hline${ }^{*}$ Alghamdi et al. (2014) & & $\sqrt{ }$ & & & & & & $\sqrt{ }$ & & \\
\hline${ }^{*}$ Alves et al. (2014) & & & & & & & & & & $\sqrt{ }$ \\
\hline *Hartini et al. (2007) & $\sqrt{ }$ & & & & $\sqrt{ }$ & & & & & \\
\hline${ }^{*}$ Weerakkody et al. (2011) & & & $\sqrt{ }$ & & & & $\sqrt{ }$ & & & \\
\hline Axelsson et al. (2011). & & & & & & & & $\sqrt{ }$ & & \\
\hline Heeks (2003) & & & & & & & & $\sqrt{ }$ & & \\
\hline Jurisch et al. (2012) & & & & & & & & & $\sqrt{ }$ & $\sqrt{ }$ \\
\hline Kennedy, et al. (2012) & & & $\sqrt{ }$ & $\sqrt{ }$ & & & & & $\sqrt{ }$ & \\
\hline McAdam and Donaghy (1999) & & $\sqrt{ }$ & & & & & & & & \\
\hline Meier, et al. (2013) & & & & & & $\sqrt{ }$ & & & & \\
\hline
\end{tabular}

Table 9: Summary of Factors Defined Under Preparedness for Organisational Change

When the developed and developing country contexts were compared, factors such as 'staff involvement', 'use of external consultants', 'rewards \& benefits' and 'development of communication strategies' for effective change management were discussed across both contexts; whereas 'job rotation/re-deployment', 'social influence', and 'training \& development', were not mentioned in the literature on developing countries. On the other hand, 'management of potential impact', 'departmental integration' and 'power distribution' factors were not mentioned in the literature related to developed countries.

Socio-cultural, socio-technical, political and organisational differences between developed and developing countries suggest BPM related change will be experienced differently. Questions proposed here include: 'What constitutes a well-designed organisational change strategy in a public sector BPM initiative?', 'How can social and cultural factors in public sector organisations influence a 
BPM initiative, in particular for better stakeholder engagement?' and 'How can training $\mathcal{E}$ development be designed to support effective BPM change in the public sector?'

\subsection{Enlisting Customer and Other External Stakeholder Support/Involvement}

The term customer-focused is no longer alien to public sector organisations. Due to major policy changes and transformation initiatives, government agencies are becoming more citizen-centric (Al-Kibsi et al., 2001; Almarabeh \& AbuAli, 2010; Borras, 2012; Heeks, 2008a). Al-Kibsi et al. (2001) and McAdam and Donaghy (1999) suggest the reorganisation of processes around the needs of citizens to achieve the full potential of BPM and e-Governance and Al-Mashari and Zairi (1999) have offered a broader perspective with emphasis on customer research, competitive analysis and benchmarking as critical elements of successful BPM efforts. In comparison with the above, Borman and Janssen (2012) emphasised incorporating the functional requirements of the stakeholders when designing interoperable system functionality, while Borras (2012) emphasised the need for user focus, citizen-centric delivery, citizen empowerment, and cross sector partnership for successful e-Government. Furthermore, the literature also emphasised on the alignment of stakeholder goals as a key element of success in e-Government projects (Kwamena, 2012; Nfuka \& Rusu, 2011; Ravesteyn \& Batenburg, 2010). Table 10 provides an overview of attributes discussed in the literature.

\begin{tabular}{|c|c|c|c|c|c|c|c|}
\hline $\begin{array}{l}(*) \text { represents developing } \\
\text { countries }\end{array}$ & 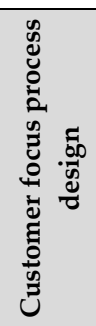 & 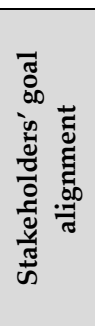 & 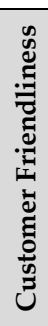 & 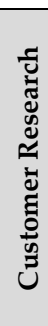 & 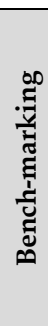 & 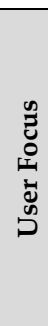 & 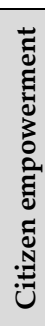 \\
\hline *Kennedy et al. (2012) & $\sqrt{ }$ & & $\sqrt{ }$ & & & & \\
\hline *Nfuka and Rusu (2011) & & $\sqrt{ }$ & & & & & \\
\hline Al-Kibsi et al. (2001) & $\sqrt{ }$ & & $\sqrt{ }$ & & & & \\
\hline Al-Mashari and Zairi (1999) & & & & $\sqrt{ }$ & $\sqrt{ }$ & & \\
\hline Borman and Janssen (2012) & $\sqrt{ }$ & & & & & $\sqrt{ }$ & \\
\hline Borras (2012) & $\sqrt{ }$ & & & & & $\sqrt{ }$ & $\sqrt{ }$ \\
\hline Gulledge and Sommer (2002) & & & & & $\sqrt{ }$ & & \\
\hline Kwamena (2012) & $\sqrt{ }$ & $\sqrt{ }$ & & & & & \\
\hline McAdam and Donaghy (1999) & $\sqrt{ }$ & & $\sqrt{ }$ & $\sqrt{ }$ & & & \\
\hline Ravesteyn and Batenburg (2010) & & $\sqrt{ }$ & & & & & \\
\hline
\end{tabular}

Table 10: Summary of Factors Defined Under Stakeholder Support/Involvement

The analysis identified a stronger emphasis on the use of 'customer focused process design' within literature on developed countries. 'Stakeholders goal alignment', and 'customer friendliness' factors were discussed across both developing and developed contexts. However, aspects such as 'customer research', 'benchmarking', 'user focus (understanding of crossfunctional users' technical requirements)', and 'citizen empowerment' were not discussed in the literature on developing countries. With citizen focussed government services being the key objective in many public sector BPM projects, the questions 'How to effectively engage the key stakeholders in public sector BPM initiatives?' and 'What are the innovative stakeholder engagement models that enable BPM success in public sector contexts?' need further investigation. 


\subsection{Choosing the BPM Team}

A sound BPM team is known to be a coherent cross-functional group, skilled with relevant technical and management techniques to lead the BPM implementation (Al-Mashari \& Zairi, 1999). The appointment of core cross-functional specialist groups in public sector BPM initiatives was supported in the literature (Al-Mashari \& Zairi, 1999; Kennedy et al., 2012; McAdam \& Donaghy, 1999). Al-Mashari and Zairi (1999) suggested the role of consultants to overcome skill shortages in government organisations. Kwamena (2012) linked the success of e-Government projects with effective management and team skills \& competencies. To overcome resource and skill shortages in public sector BPM projects, Alves et al. (2014) proposed the establishment of a BPM Office, a dedicated organisational unit to deliver BPM services. Studies by Nfuka and Rusu (2011) and Borras (2012) stressed human resource planning, recruitment, development and retention of qualified technical staff. Dexter (2010) emphasised the optimal combination of individuals based on skill, roles, type, and willingness to learn as key factors for teams. The lack of required IS/IT capabilities and skills, and partnerships with industry experts in e-Government projects were mentioned as constraining factors (Alghamdi et al., 2014; Weerakkody, El-Haddadeh, et al., 2011). Table 11 presents a summary of sub-factors.

\begin{tabular}{|c|c|c|c|c|}
\hline${ }^{(*)}$ represents developing countries & 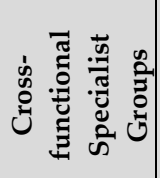 & 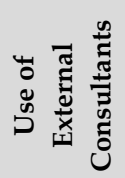 & 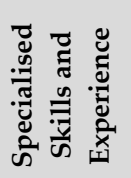 & 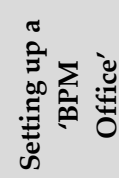 \\
\hline${ }^{*}$ Alghamdi et al. (2014) & & & $\sqrt{ }$ & \\
\hline${ }^{*}$ Alves et al. (2014) & $\sqrt{ }$ & & $\sqrt{ }$ & $\sqrt{ }$ \\
\hline${ }^{*}$ Weerakkody et al. (2011) & & $\sqrt{ }$ & $\sqrt{ }$ & \\
\hline Al-Mashari and Zairi (1999) & $\sqrt{ }$ & $\sqrt{ }$ & $\sqrt{ }$ & \\
\hline Borras (2012) & & $\sqrt{ }$ & $\sqrt{ }$ & \\
\hline Dexter (2010) & & & $\sqrt{ }$ & \\
\hline Kennedy et al. (2012) & $\sqrt{ }$ & & & \\
\hline McAdam and Donaghy (1999) & $\sqrt{ }$ & & $\sqrt{ }$ & \\
\hline
\end{tabular}

Table 11: Aspects to Consider for BPM Team Selection

'Specialised skills and experience' was emphasised in the literature in both developing and developed country contexts, however, with most details predominantly discussing ICT and technical skills. On the other hand, the need for 'setting up a BPM Office' (or having a dedicated entity for BPM within the organisation) was mentioned only in a single study (in a developing country context). 'Cross-functional specialist group', and the 'use of external consultants' were mentioned in both contexts.

Although the 'skill set' and the call for a 'right mix' was repeatedly discussed by various authors, the definitions and description of these concepts still need further clarification. Furthermore, skills were mostly attributed towards ICT and technical skills development, whereas based on the above discussion, it is observed that a majority of literature lacked details on BPM specific skills and competencies. This leaves the question 'What constitutes an effective BPM team in public sector contexts?' unanswered.

BPM is still in its introductory stages in developing countries and due to the lack of resources and skills development opportunities (Bandara et al., 2012), there is a need for robust human resource planning, training and development strategies. Considering the above discussion, we 
deduce that BPM knowledge and skill development in developing countries require attention. Thus, 'How to develop BPM capabilities (in general) in developing countries?' can be a focus for future research.

\subsection{Alleviation of Downsizing Fears (Resistance to Change)}

Resistance to change can influence the actual or expected outcomes related to BPM. BPM brings radical change to organisational structures, which is often perceived as a threat (Alves et al., 2014; Axelsson et al., 2011; McAdam \& Donaghy, 1999). Employees who fear the loss of authority and choice due to the introduction of technology and ICT-enabled processes show higher resistance to change (Meier et al., 2013; Weerakkody, El-Haddadeh, et al., 2011). Job security (McAdam \& Donaghy, 1999) was a key factor of concern for operational staff. Marilu (2012), on the other hand, attributed the fear of job loss to the frontline and middle management staff in the government sector. Borman and Janssen (2012), suggested the need for union and staff relationship management to handle changes to jobs and reskilling needs and Hartini et al. (2007) stressed the use of intrinsic and extrinsic motivational strategies to overcome resistance to change and fear of uncertainty. Al-Kibsi et al. (2001) on the other hand recommended government employees' involvement in the process to overcome resistance, while Kamal (2006) recommended that resistance to change can be effectively addressed by introducing the role of influential and tech-savvy champions. Table 12 presents the identified sub-factors.

\begin{tabular}{|c|c|c|c|c|}
\hline (*) represents developing countries & 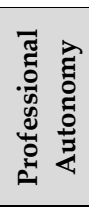 & 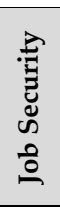 & 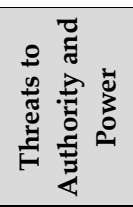 & 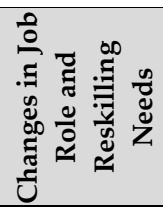 \\
\hline Alves et al. (2014) & $\sqrt{ }$ & & $\sqrt{ }$ & \\
\hline${ }^{*}$ Hartini et al. (2007) & & $\sqrt{ }$ & & \\
\hline "Weerakkody et al. (2011) & & & $\sqrt{ }$ & \\
\hline Axelsson et al. (2011). & & & $\sqrt{ }$ & $\sqrt{ }$ \\
\hline Borman and Janssen (2012) & & & & $\sqrt{ }$ \\
\hline Marilu (2012) & & $\sqrt{ }$ & & \\
\hline McAdam and Donaghy (1999) & $\sqrt{ }$ & $\sqrt{ }$ & $\sqrt{ }$ & \\
\hline Meier et al. (2013) & & $\sqrt{ }$ & & \\
\hline
\end{tabular}

Table 12: Summary of Attributes Underpinning Downsizing Fears

'Professional autonomy', 'job security', and 'threats to authority and power' were the common sub-factors mentioned for resistance. Whereas 'changes in job roles and reskilling needs' was not mentioned in studies on developing countries. Considering the above discussion, 'What are the key contributing factors that lead to resistance to change for BPM in public sector organisations?' is an important aspect that requires further investigation. Furthermore, McAdam and Donaghy (1999) identified a higher level of resistance to change within operational staff, whereas Marilu (2012) relates it to front-line and middle management staff. This anomaly warrants further understanding of which level of staff in a government organisation may exhibit higher resistance to change; thus questions to further investigate can be; 'Does resistance to change for BPM differ between staff at different levels in public sector contexts?' and 'How to identify the most vulnerable staff groups within government departments about to deploy $B P M$, and anticipate reactions?'. 


\subsection{Empowerment}

Empowerment can address the provision of delegation of authority, responsibility, and accountability issues to the BPM team. Al-Mashari and Zairi (1999), reported that empowerment helps create collaborative teamwork cultures and as a result, staff at all levels take greater responsibility and accountability. The absence of empowerment will have negative consequences on e-Government initiatives (Weerakkody, El-Haddadeh, et al., 2011). $\mathrm{BPM}$ often requires changing the organisational structure, and attempts to implement BPM within hierarchical organisational structures (i.e. public sector) increase the likelihood of failure (Gulledge \& Sommer, 2002). McAdam and Donaghy (1999) defined empowerment as the direct involvement of staff at all levels and the incorporation of their opinions in the process mapping exercise. In comparison, Doebeli et al. (2011) linked empowerment with the directing and controlling aspects of management. Hartini et al. (2007) emphasised a robust organisational structure to overcome bureaucracies and improvement of staff participation in decision making. In contrast, Marilu (2012) and Alghamdi et al. (2014) explained empowerment as the management mandate to delegate, budget, resource, control, and for the division of authority. Table 13 provides a summary of various sub-factors discussed in the context of empowerment in public sector BPM projects.

\begin{tabular}{|c|c|c|c|c|c|}
\hline$\left(^{*}\right)$ represents developing countries & 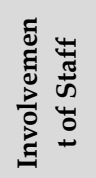 & 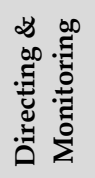 & 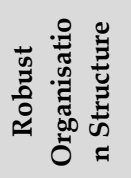 & 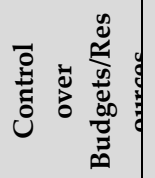 & 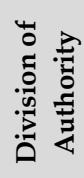 \\
\hline${ }^{*}$ Alghamdi et al. (2014) & & & & $\sqrt{ }$ & $\sqrt{ }$ \\
\hline${ }^{*}$ Hartini et al. (2007) & $\sqrt{ }$ & & $\sqrt{ }$ & & \\
\hline Doebeli, et al. (2011) & & $\sqrt{ }$ & & & \\
\hline Gulledge and Sommer (2002) & & & $\sqrt{ }$ & & \\
\hline Marilu (2012) & & & & $\sqrt{ }$ & $\sqrt{ }$ \\
\hline McAdam and Donaghy (1999) & $\sqrt{ }$ & & $\sqrt{ }$ & & \\
\hline
\end{tabular}

Table 13: Summary of Attributes Contributing to Empowerment

Except for the 'Directing \& monitoring' factor (which was mentioned in one paper from the developing country context), all the sub-factors were identified in both developing and developed contexts. Although empowerment is recognised as a key component for BPM initiatives, there is limited discussion on the description of the dynamics of empowerment and the manner and processes in which empowerment can be established. As Likert (1961) argued, empowerment should not be equated with staff participation and involvement without proper delegation of authority, accountability and responsibility.

Public sector organisations are driven by hierarchical, top down approaches (Hutton, 1996; Tregear \& Jenkins, 2007), and these characteristics are different to organisational structures that are naturally more empowering, therefore raising the following questions; 'How can public sector organisations be receptive to employee empowered bottom-up BPM approaches?', and 'How to create a sense of empowerment amongst public sector employees to support sustained BPM success?' as areas for further investigation. Furthermore, organisational structures and management approaches in developing countries towards empowerment of staff through delegation of power and decentralised decision making can be quite different compared to developed countries (Chen et al., 2006). A deeper understanding of these differences and their impact on 
public sector BPM is required, hence 'What organisational structures would best provide accountability, responsibility, and authority to enable Public Sector BPM success?

\subsection{ICT Infrastructure}

A robust ICT Infrastructure is vital for collection and dissemination of information. While Kamal (2006) states technology systems are needed for effective communication, Borras (2012) described the interoperability (open standards and support), web-centric delivery (service oriented architecture), agility (re-usability, flexibility, adaptability) and shared services (common data sets, authentication) as the key components of ICT Infrastructure for successful transformational government projects. Weerakkody, El-Haddadeh, et al. (2011) have taken the perspective of both implementers and users of e-Government and identified security, privacy, and IT standards as the critical concerns in e-Government projects in developing countries. Nfuka and Rusu (2011) suggested the need to consolidate, standardise, and manage IT infrastructure for cost optimisation and effective information flow. Al-Mashari and Zairi (1999) explained the adequacy, reassessment and composition of IT infrastructure as vital factors in successful BPR implementation. Alves et al. (2014) reported that organisations with successful BPM experience had good technical infrastructure (e.g. software tools, supporting communication facilities) and positive synergy among units participating in BPM initiatives. Table 14 illustrates the sub-factors related to ICT infrastructure.

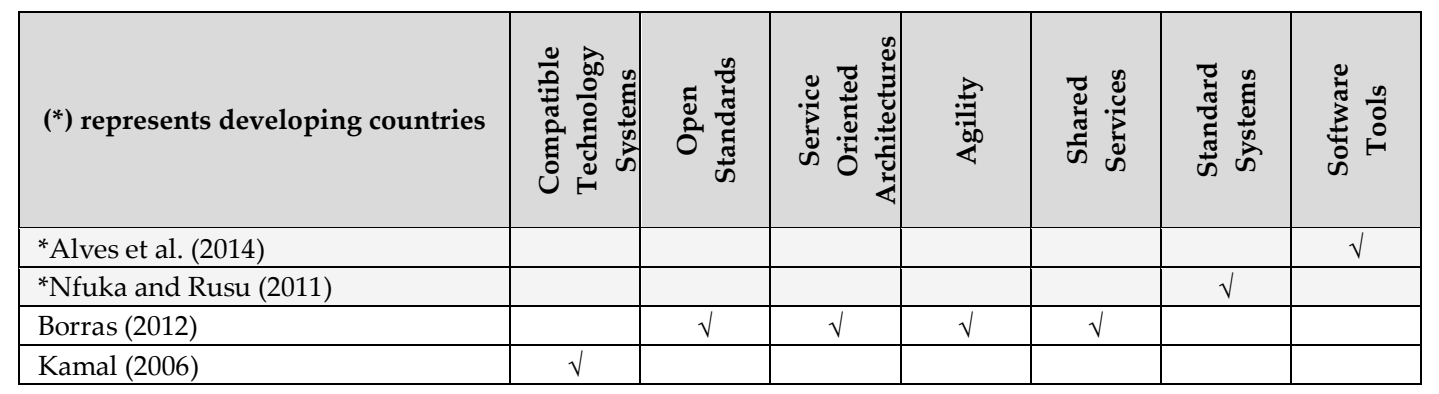

Table 14: Attributes underpinning ICT Infrastructure

As Ward and Peppard (2002) stated, due to continuous technology evolution, defining IT infrastructure and its components have become increasingly difficult. From the limited studies here, prior research on BPM in the public sector also faced similar IT infrastructure challenges. Although difficult to comment conclusively on any differences between developed and developing countries with the limited related papers on this CSF as shown in Table 14, literature on developing countries refers to ICT infrastructure as software tools and standard systems to improve interoperability to enable seamless integration and sharing of data. On the other hand, literature on developed countries reflects the attention on interoperability, shared services and integrated aspects of ICT infrastructure. According to current trends, developing countries are starting to move away from standalone systems to build more integrated ICT infrastructure to provide one-stop-shop service platforms (United Nations, 2016). Further research on innovative, emerging ICT infrastructure models to address 'How can governments in developing countries best design and benefit from the use of emerging new ICT options such as; shared services, cloud computing, open source, etc.?', can be proposed. 


\subsection{Project Management and Project Management Skills}

Project management is an integral part of BPM projects in the public sector. Hartini et al. (2007) observed that the practice of training staff in project management by deploying external consultants resulted in effective BPM implementations. Marvine, Martin, Doaa, and Salah (2012) compared the differences between public sector and private sector programmes and advocated the essential need to contextualise project management skills, knowledge, tools, and techniques to individual local contexts in order to meet project objectives. Al-Mashari and Zairi (1999) confirmed planning, project management techniques, risk assessment, sufficiency of budgets, and human resource management as key factors in delivering a successful BPM project. Weerakkody, El-Haddadeh, et al. (2011) discuss prioritisation strategies demonstrating the value of narrowing the focus to first delivering the most strategically significant services.

The consensus over the importance of project management is evident in the literature. Most definitions and findings though narrowly describing the stages and techniques of project management, have acknowledged the need for project management as a vital feature for BPM projects. Table 15 illustrates the related sub-factors as discussed in the literature.

\begin{tabular}{|c|c|c|c|c|c|c|c|c|}
\hline$\left.{ }^{*}\right)$ represents developing countries & 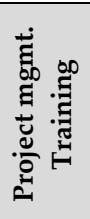 & 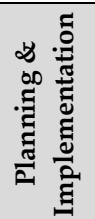 & 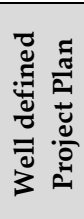 & 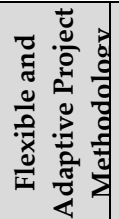 & 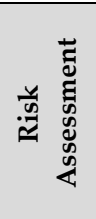 & 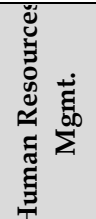 & 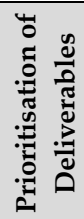 & $\begin{array}{l}\infty \\
0 \\
0 \\
0 \\
0 \\
0\end{array}$ \\
\hline${ }^{*}$ Hartini et al. (2007) & $\sqrt{ }$ & & & & & & & \\
\hline${ }^{*}$ Marvine, et al. (2012) & $\sqrt{ }$ & & & $\sqrt{ }$ & & & & \\
\hline *Weerakkody, et al. (2011) & & & & & & & $\sqrt{ }$ & \\
\hline Al-Mashari and Zairi (1999) & $\sqrt{ }$ & $\sqrt{ }$ & & & $\sqrt{ }$ & $\sqrt{ }$ & & $\sqrt{ }$ \\
\hline Jurisch et al. (2012) & & $\sqrt{ }$ & $\sqrt{ }$ & $\sqrt{ }$ & $\sqrt{ }$ & $\sqrt{ }$ & & $\sqrt{ }$ \\
\hline Kwamena (2012) & $\sqrt{ }$ & & & & $\sqrt{ }$ & & & \\
\hline
\end{tabular}

Table 15: Summary of Factors Defined Under Project Management and Project Management Skills

The analysis indicated a considerable gap in project management and relevant skills in the developing countries. An observed key gap in the body of literature was the limited detail on how project management is embedded within standard BPM methodologies. The current literature discusses these as two discrete approaches, which should in reality be tightly integrated and complimenting each other. Therefore, research on 'How to integrate project management practices into BPM methodology?' is recommended to strengthen the integration between project management and BPM methodology. Some papers vividly discuss the need for (and the gaps in) project management training. One reason for high failure rates in public sector BPM is attributed to the project management practices, pointing to the need to investigate 'How to ensure effective project management training and training transfer in public sector?' and 'How to build project management awareness in public sector BPM contexts?'

\subsection{ICT - Awareness}

ICT Awareness may be used to assess and develop the required technical and process competencies. A large body of literature emphasised the need for ICT awareness and effective training (Al-Mashari \& Zairi, 1999; Alghamdi et al., 2014; Alves et al., 2014; Borman \& Janssen, 2012; Hartini et al., 2007; Heeks, 2003). Hisham et al. (2012) associated user satisfaction with the success of e-government and recommended the use of ICT training for public sector 
officers to achieve higher user satisfaction. Alghamdi et al., (2014) emphasised the use of regulations and the need for technical support to improve ICT awareness.

On a different note, Kamal (2006) linked technical competence and expertise of the IT Manager to gain top management's support and trust. Similar emphasis on technical competence for successful project execution in e-Government projects was suggested by Kwamena (2012). Reskilling and training and development were the common factors discussed in the literature in both the developed and developing contexts. Literature on developed countries further discussed 'interoperability', 'IT manager's expertise' and 'user-friendliness' aspects, whereas 'technical support' and use of 'regulations' is given much attention by the literature on developing countries. Sub-factors related to ICT awareness are presented in Table 16.

\begin{tabular}{|c|c|c|c|c|c|c|}
\hline${ }^{*}$ ) represents developing countries & 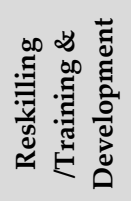 & 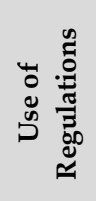 & 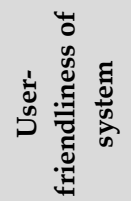 & 竞 & 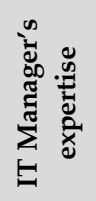 & 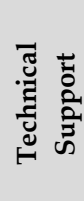 \\
\hline${ }^{*}$ Alghamdi et al. (2014) & $\sqrt{ }$ & $\sqrt{ }$ & & & & $\sqrt{ }$ \\
\hline${ }^{*}$ Alves, et al. (2014) & $\sqrt{ }$ & & & & & \\
\hline${ }^{*}$ Hartini et al. (2007) & $\sqrt{ }$ & & & & & \\
\hline${ }^{*}$ Hisham et al. (2012) & $\sqrt{ }$ & & & & & \\
\hline Borman \& Janssen (2012) & $\sqrt{ }$ & & & & & \\
\hline Borras (2012) & & & & $\sqrt{ }$ & & \\
\hline Heeks (2003) & $\sqrt{ }$ & & & & & \\
\hline Jurisch et al. (2012) & $\sqrt{ }$ & & & & & \\
\hline Kamal (2006) & & & $\sqrt{ }$ & & $\sqrt{ }$ & \\
\hline
\end{tabular}

Table 16: Summary of Factors Defined Under ICT Awareness

The analysis illustrated the lack of awareness on BPM capabilities, confirming the findings of Bandara et al. (2012), who highlights the need to develop much needed BPM skills and competencies in public sector organisations. The BPM training needs analysis, design and conduct options (the methods, types, and durations of these training and development programmes), and training evaluations seem to be an obvious gap requiring further investigation. Hence, an investigation on; 'How to ensure effective BPM training and training transfer in public sector organisations?' is warranted. BPM and ICT have a recursive relationship (Attaran, 2004; Davenport \& Short, 1990), hence, development of organisational BPM skills are as important as ICT skills; however they were rarely discussed in the current literature. We propose that an investigation on the following; 'How does training in BPM skills improve BPM success in Public sector organisations?' and 'How can public sector organisations proactively use ICT for BPM efforts?' can help progress BPM in the public sector.

\subsection{Culture}

As the culture factor represents the organisational core value system, shared beliefs and norms, it appears to interact and shape other organisational factors. Hartini et al. (2007), emphasised the development of a strong culture in the organisation by the innovative incorporation of core values. Maintaining a process-oriented culture is easier when systems are aligned with the processes (Gulledge \& Sommer, 2002). Tan, Cater-Steel, and Toleman (2009) emphasised that public sector organisations should shift their culture from the technological to a service-focused culture. Alves et al. (2014) construed process orientation as a key aspect of culture. Weerakkody et al. (2011) recognised the importance of culture and its 
influences on the implementation and dissemination of e-Government. Table 17 illustrates the sub-factors discussed in the literature.

\begin{tabular}{|c|c|c|c|c|c|c|c|c|c|}
\hline (*) represents developing countries & 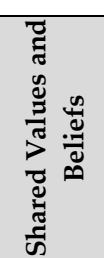 & 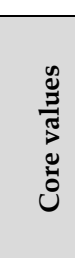 & 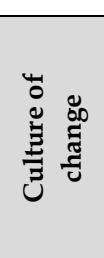 & 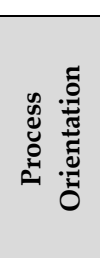 & 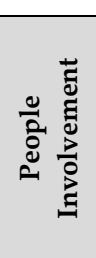 & 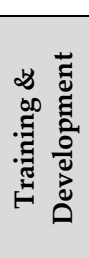 & 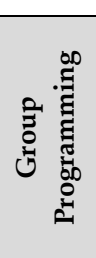 & 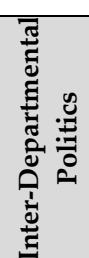 & 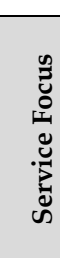 \\
\hline${ }^{*}$ Alves et al. (2014) & & & & $\sqrt{ }$ & & & & & \\
\hline *Hartini et al. (2007) & $\sqrt{ }$ & $\sqrt{ }$ & & & $\sqrt{ }$ & & & & \\
\hline *Valenca, et.al (2013) & & & & $\sqrt{ }$ & & & & & \\
\hline *Weerakkody et al. (2011) & & & & & & & $\sqrt{ }$ & & \\
\hline Al-Mashari and Zairi (1999) & $\sqrt{ }$ & & $\sqrt{ }$ & & $\sqrt{ }$ & $\sqrt{ }$ & & & \\
\hline Al-Kibsi (2001) & & & & & & & & $\sqrt{ }$ & \\
\hline Gulledge and Sommer (2002) & & & & $\sqrt{ }$ & & & & & \\
\hline Wui-gee Tan et al (2009) & & & & & & & & & $\sqrt{ }$ \\
\hline
\end{tabular}

Table 17: Summary of Factors Defined Under Culture

The identified sub-elements of organisational culture were parsimoniously touched upon by studies in both developed and developing contexts. Most literature related culture with the resistance to change. We believe that the public sector organisations' culture itself is a standalone research topic because of the unique socio-economic, ethnic, and political dynamics that exist both in developed as well as developing countries (Chen et al., 2006; Tregear \& Jenkins, 2007). Therefore, the question 'How to develop mechanisms to implement robust and innovative process-centric cultures in the public sector?' can be posed. Just as Hofstede (1984) established distinct differences between western and eastern cultures that affect organisational planning and management, it can also be expected that organisational cultures in developing countries can have different complex layers (Chen et al., 2006; Weerakkody, El-Haddadeh, et al., 2011). Hence, it is vital to be able to assess 'How organisational culture and its characteristics in developing countries uniquely affect BPM initiatives in public sector organisations?'

\subsection{IT-BPM Governance}

Process governance provides a reference framework to guide organizational units to ensure responsibility and accountability to lead the BPM initiative (Alves et al., 2014). While incorporating the general features of governance, the attention of BPM governance is on processes (Doebeli et al., 2011). Few papers discussed about the IT Governance in public sector BPM initiatives where IT played a central role as the process enabler. We combined the two terms as IT-BPM Governance CSF.

Doebeli et al. (2011, p. 199) stated that "the integration of BPM roles and responsibilities into the governance management system of the organisation ensures sustainability of the practice and business improvement efforts". Nfuka and Rusu (2011) concur the importance of IT Governance and its awareness, training, and competency of professionals as an influencing factor for IT Governance to a sustainable, standardised and cost-effective IT environment. Furthermore, Alves et al. (2014) suggested that BPM maturity in an organisation will improve by establishing a BPM office and reference framework. Borman \& Janssen (2012) recommended the establishment of guidelines and processes, as well as unified organisational structure in which all stakeholder organisations should be grouped to reduce complexity leading to 
effective governance. A summary of the sub-factors IT-BPM Governance is presented in Table 18.

\begin{tabular}{|c|c|c|c|c|c|c|c|c|}
\hline$\left(^{*}\right)$ represents developing countries & 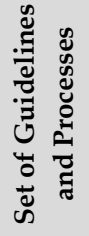 & 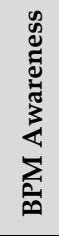 & 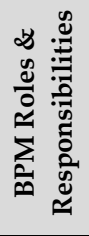 & 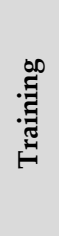 & 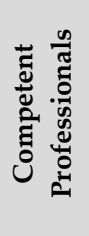 & 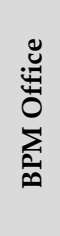 & 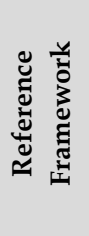 & 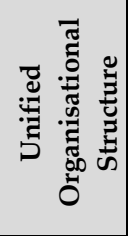 \\
\hline${ }^{*}$ Nfuka and Rusu (2011) & & $\sqrt{ }$ & & $\sqrt{ }$ & 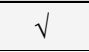 & & & \\
\hline *Alves et al. (2014) & $\sqrt{ }$ & & & & & $\sqrt{ }$ & $\sqrt{ }$ & \\
\hline *Valenca, et.al (2013) & & & $\sqrt{ }$ & & & $\sqrt{ }$ & & \\
\hline Borman \& Janssen (2012) & v & & & & & & & $\sqrt{ }$ \\
\hline Doebeli (2011) & & & v & & & & & \\
\hline
\end{tabular}

Table 18: Attributes Underpinning IT-BPM Governance

The analysis indicated a higher emphasis on IT-BPM governance in the literature on developing countries. 'BPM awareness', 'training', 'competent professionals', 'BPM office', and 'Reference frameworks' (in the context of governance) were not discussed in papers from developed countries. Only two studies on developed countries on this important topic reflected a generic lack of literature in this area. While a diverse set of sub-factors pertaining to IT-BPM governance in the public sector are discussed in the literature, clear normative guidelines on how to set effective, holistic BPM governance in public sector settings has been given little attention. In recognition that there are many BPM governance models out there, we propose future research that investigates; 'How to best select, adopt and deploy BPM governance frameworks in public sector settings?' We also see value in specifically investigating the roles and responsibilities aspect, and hence propose future research that investigates 'How can BPM-related roles and responsibilities be effectively designed and managed in public sector settings?'

\subsection{Strategic Clarity \& Alignment}

The review of literature identified two different points of view related to strategic clarity and alignment. According to Borras (2012), it is setting a clear vision, business case, and result focused strategy for e-Government initiatives. More inclusive definitions demarcated strategic alignment as the interrelationship between strategic goals for an e-Government project and the overall government's vision and mission (Kwamena, 2012; Marilu, 2012). Contrary to these, Kamal (2006) defined it as the suitability of the system with the organisational need and organisational compatibility for cross-departmental information sharing. On similar lines, Nfuka and Rusu (2011, p. 1436) mentioned it as "alignment of IT with business strategies and enabling IT structures. This can make possible successful integration of IT with effects in the public service delivery improvement in and across these widespread organizations" The above was strongly supported by Weerakkody et al. (2011) who linked the lack of alignment of the e-Government plan as the key factor for failure of service delivery. Table 19 illustrates the sub-factors that were discussed by the literature. 


\begin{tabular}{|c|c|c|c|c|c|}
\hline$(*)$ represents developing countries & పี & 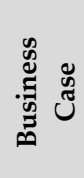 & 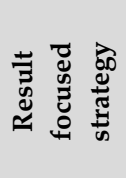 & 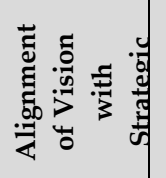 & 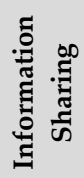 \\
\hline${ }^{*}$ Nfuka and Rusu (2011) & & & & $\sqrt{ }$ & \\
\hline${ }^{*}$ Weerakkody et al. (2011) & & & & $\sqrt{ }$ & \\
\hline Borras (2012) & $\sqrt{ }$ & $\sqrt{ }$ & $\sqrt{ }$ & & \\
\hline Gulledge and Sommer (2002) & & & & $\sqrt{ }$ & \\
\hline Kamal (2006) & & & & & $\sqrt{ }$ \\
\hline Kwanmena (2012) & $\sqrt{ }$ & & & $\sqrt{ }$ & \\
\hline Marilu (2012) & & & & $\sqrt{ }$ & \\
\hline
\end{tabular}

Table 19: Summary of Attributes of Strategic Clarity and Alignment

Studies related to both developed and developing countries showed the 'alignment of vision with strategic goals' as a common factor. Literature on developing countries did not discuss the other factors as presented by the literature on developed countries. There is value in investigating and clearly articulating 'How can BPM initiatives be best aligned with the strategic directions - especially in public sector settings?' which can guide public sector organisations to gain better strategic alignment of their BPM initiatives.

\subsection{External Environmental Factors}

External environmental factors that include socio-economic factors (national income, political structure, literacy, population characteristics, etc.) can influence activities of a BPM enabled transformation. Kamal (2006) lists a number of sub-factors as key influencing environmental factors that can affect adoption of innovations in government organisations. Marvine et al. (2012) referred to controls and laws and regulations as such contributing external environmental sub-factors. Sub-factors related to External Environmental Factors are presented in Table 20.

\begin{tabular}{|c|c|c|c|c|c|c|}
\hline$\left.{ }^{*}\right)$ represents developing countries & 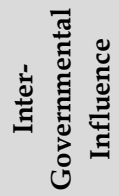 & 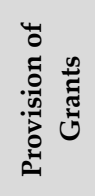 & 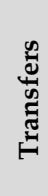 & 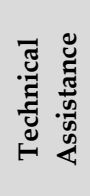 & 苞 & 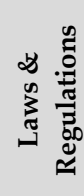 \\
\hline${ }^{*}$ Marvine et al. (2012) & & & & & $\sqrt{ }$ & $\sqrt{ }$ \\
\hline Kamal (2006) & $\sqrt{ }$ & $\sqrt{ }$ & $\sqrt{ }$ & $\sqrt{ }$ & & \\
\hline
\end{tabular}

Table 20: Summary of Attributes Underpinning External Environmental Factors

As highlighted by Sadowsky (1996), the external environment of countries is influenced by many factors that warrant careful attention. As presented in Table 20, current literature evidenced limited attention given to date to better identify and understand the influences of external environmental factors on BPM in the public sector (in both developed and developing countries). Availability and access to specialised knowledge, resources (human \& funds), political climate and administrative policies, and socio-economic/socio-ethnic compositions can significantly alter BPM enabled transformation endeavours, especially in a developing country (Chen et al., 2006). The external environment is contextual, complex and diverse, and influences all other factors. Hence, we argue that these factors need to be further analysed; and propose that future research investigate in more depth; 'What contextual factors from the external environment influence BPM initiatives in the public sector?', and also study more carefully 'How 
can these external environmental contextual factors influence other critical success factors within public sector BPM initiatives?'

\section{Summary Discussion}

The goal of this systematic literature review was to collate and analyse CSFs of BPM efforts as discussed in public sector settings, post the last such synthesis which was reported by McAdam et al. in 1999. Public sector BPM CSFs as presented in papers post 1999 were collated, analysed, clearly defined (see Table 6 ) and reported herein with special attention to elicit any mentioned sub-factors (see Tables 7- 20) to better understand each CSF. Given the differences between developing and developed contexts (as discussed above), attention was given in the analysis towards identifying any observable differences between the CSFs reported within the developed and developing contexts.

The overall analysis used a rigorous qualitative data analysis procedure following Bandara et al. (2015). The McAdam and Donaghy (1999) framework was used as the a-priori model for public sector BPM CSFs. The analysis of 31 relevant papers, all derived post McAdam and Donaghy (1999) resulted in the following:

1. Confirmation of all the McAdam and Donaghy (1999) factors (see Table 6).

2. Identification of seven new factors (see Table 6) resulting in 14 CSFs observed to be relevant to BPM in public sector organisations. Top Management Support, Communication, Alleviation of Downsizing Fears (resistance to change), ICT Awareness, Empowerment, and Enlisting Customer \& Stakeholder Support were amongst the widely discussed factors by the researchers; IT-BPM Governance and culture were the least discussed critical success factors in the body of the literature.

3. Capturing of sub-factors pertaining to each factor (with supporting literature evidence - see Table 7 to 20), and providing further insights to the CSFs and contributing towards how to action them (for practice) and/or how to operationalise them (for future research).

4. Deriving from the results a series of prospective research questions based on gaps and opportunities observed from this analysis that could shape the future research around BPM in public sector (see Table 21)

All identified CSFs (14 of them) are common to both developing and developed countries. We did not discover any distinctly different CSFs for the developing countries. This could be attributed to a number of reasons, such as:

- The limited number of papers (8) representing the developing country context in the pool of papers found.

- Limited attention given to research specifically within the developing context (Kennedy et al., 2012; Walsham et al., 2007). This could be due to the resource and skill constraints in these countries to do effective research in these specific contexts, which could also explain the very limited number of papers of the developing country context found in high quality research outlets.

- The limited research activities and practice happening in the developing country context to try to 'learn' and mimic from the strategies adopted by the developed countries with little attention given to better contextualise these to the specific 
developing country context. We believe this can further explain why the current literature identified common factors amongst the two with little differentiation.

However, sometimes a different emphasis on the sub-factors (within each main factor) was observed between developed and developing country contexts and this was discussed in detail as each CSF was presented.

As evident from this review, prior research is heavily skewed towards the developed context. The validity and suitability of these factors in a developing country context can be argued and provides an opportunity for further analysis and investigation. As posited earlier under the section titled; "Public vs Private Sector BPM - differences and similarities", BPM efforts in developing countries could differ widely for various reasons thus supporting our proposition for deeper, contextually rich studies of BPM in the public sector of developing nations to gain contextually aligned insights.

In addition, the application of existing frameworks and theories built in the developed country context may not be appropriate for developing countries for, "an interesting proposition was always the negation of an accepted one" (Davis, 1971, p313), what seems to be the case is in fact not really the case when borrowing across diverse contexts. The International Monetary Fund (2015) classified 155 countries as developing nations. With $80 \%$ of the world population residing in developing countries, governments struggle to provide key public services to their citizens in an efficient and effective way. Our search of literature identified only 8 papers constituting $26 \%$ of the studies with a focus on developing nations. Given the few papers observed in top tier IS and Business journals on this important and under-researched area, we make a call for action to editors of leading journals of our disciplines to encourage research in this area by having special issues and showing more acceptance and interest to papers from the developing context, recognising it as an innovative (untapped) area to research. We also make a call for action to researchers interested in this area to make use of this body of knowledge of CSFs pulled together in this review, and build on existing work to support cumulative knowledge creation and progression of developing country context research.

As each factor was analysed, we elicited areas deemed to be overlooked, under-researched, or with lack of empirical support, and also sought 'new ideas' worthy and in need of future research (following Alvesson and Sandberg's 2013). Following Muller-Bloch and Kranz's (2015) guidelines, we summarise our views and present a list of potential future research questions in Table 21. For ease of reading, the proposed questions (Column 2) are grouped by the CSFs (Column 1) where the questions were originally proposed in the discussions above, but are not mutually exclusive to that CSF. In other words, some of the questions proposed may directly or indirectly relate to multiple factors. Most of the proposed questions are applicable to public sector BPM research in both developed and developing country contexts unless specifically mentioned otherwise. We also acknowledge that there can be a lot of diversity within the broader groupings of developed and developing countries (i.e. based on the region, per capita income and other diverse/ country specific needs), which could influence how and where the proposed research questions in Table 21 can be adopted.

We acknowledge the subjectivity of these suggested future research questions in recognition that they were derived from our interpretations which are potentially influenced by our world views, other literature we have read, and our own areas of research interests. However, such subjectivity is expected in any gap-spotting exercise (Alvesson and Sandberg, 2013). Further 
literature outside the scope of this review was referred to at times to confirm the gaps presented here.

\begin{tabular}{|c|c|}
\hline \multirow{4}{*}{$\begin{array}{l}\text { 1. Top Management } \\
\text { Support }\end{array}$} & $\begin{array}{l}\text { How can top management support within public sector BPM initiatives be } \\
\text { conceptualised? }\end{array}$ \\
\hline & $\begin{array}{l}\text { How does leadership contribute to the success and sustainability of BPM in the public } \\
\text { sector? }\end{array}$ \\
\hline & How to build leadership capabilities on process-centric innovation in public sector? \\
\hline & $\begin{array}{l}\text { How to obtain sustained long term top management commitment for BPM in public } \\
\text { sector? }\end{array}$ \\
\hline \multirow[b]{2}{*}{ 2. Communication } & What are the essential elements of a public sector BPM communication plan? \\
\hline & $\begin{array}{l}\text { Who are public sector BPM stakeholders and what are their potential impacts on BPM } \\
\text { efforts? }\end{array}$ \\
\hline \multirow{3}{*}{$\begin{array}{l}\text { 3. Preparedness for } \\
\text { Organisational } \\
\text { Change }\end{array}$} & $\begin{array}{l}\text { What constitutes a well-designed organisational change strategy in a public sector BPM } \\
\text { initiative? }\end{array}$ \\
\hline & $\begin{array}{l}\text { How can social and cultural factors in public sector organisations influence a BPM } \\
\text { initiative, in particular for better stakeholder engagement? }\end{array}$ \\
\hline & $\begin{array}{l}\text { How can training \& development be designed to support effective BPM change in the } \\
\text { public sector? }\end{array}$ \\
\hline \multirow{2}{*}{$\begin{array}{l}\text { 4. } \\
\text { Enlisting } \\
\text { Customer and } \\
\text { Stakeholder } \\
\text { Support / } \\
\text { Involvement }\end{array}$} & How to effectively engage the key stakeholders in public sector BPM initiatives? \\
\hline & $\begin{array}{l}\text { What are the innovative stakeholder engagement models that enable BPM success in } \\
\text { public sector contexts? }\end{array}$ \\
\hline \multirow{2}{*}{$\begin{array}{l}\text { 5. Choosing the } \\
\text { BPM Team }\end{array}$} & What constitutes an effective BPM team in public sector contexts? \\
\hline & How to develop BPM capabilities (in general) in developing countries? \\
\hline \multirow{3}{*}{$\begin{array}{l}\text { 6. Alleviation of } \\
\text { Downsizing } \\
\text { Fears (Resistance } \\
\text { to Change) }\end{array}$} & $\begin{array}{l}\text { What are the key contributing factors that lead to resistance to change for BPM in public } \\
\text { sector organisations? }\end{array}$ \\
\hline & $\begin{array}{l}\text { Does resistance to change for BPM differ between staff at different levels in public sector } \\
\text { contexts? }\end{array}$ \\
\hline & $\begin{array}{l}\text { How to identify the most vulnerable staff groups within government departments about } \\
\text { to deploy BPM, and anticipate reactions? }\end{array}$ \\
\hline \multirow{3}{*}{ 7. Empowerment } & $\begin{array}{l}\text { How can public sector organisations be receptive to employee empowered bottom-up } \\
\text { BPM approaches? }\end{array}$ \\
\hline & $\begin{array}{l}\text { How to create a sense of empowerment amongst public sector employees to support } \\
\text { sustained BPM success? }\end{array}$ \\
\hline & $\begin{array}{l}\text { What organisational structures would best provide accountability, responsibility, and } \\
\text { authority to enable Public Sector BPM success? }\end{array}$ \\
\hline $\begin{array}{l}\text { 8. ICT } \\
\text { Infrastructure }\end{array}$ & $\begin{array}{l}\text { How can governments in developing countries best design and benefit from the use of } \\
\text { emerging new ICT options such as; shared services, cloud computing, open source, etc.? }\end{array}$ \\
\hline \multirow{3}{*}{$\begin{array}{l}\text { 9. Project } \\
\text { Management } \\
\text { and PM Skills }\end{array}$} & How to integrate project management practices into BPM methodology? \\
\hline & $\begin{array}{l}\text { How to ensure effective project management training and training transfer in public } \\
\text { sector? }\end{array}$ \\
\hline & How to build project management awareness in public sector BPM contexts? \\
\hline \multirow{3}{*}{ 10. ICT-Awareness } & $\begin{array}{l}\text { How to ensure effective BPM training and training transfer in public sector } \\
\text { organisations? }\end{array}$ \\
\hline & How does training in BPM skills improve BPM success in Public sector organisations? \\
\hline & How can public sector organisations proactively use ICT for BPM efforts? \\
\hline
\end{tabular}




\begin{tabular}{|l|l|}
\hline \multirow{2}{*}{ 11. Culture } & $\begin{array}{l}\text { How to develop mechanisms to implement robust and innovative process-centric cultures } \\
\text { in the public sector? }\end{array}$ \\
\cline { 2 - 2 } & $\begin{array}{l}\text { How organisational culture and its characteristics in developing countries uniquely affect } \\
\text { BPM initiatives in public sector organisations? }\end{array}$ \\
\hline \multirow{3}{*}{$\begin{array}{l}\text { 12. IT-BPM } \\
\text { Governance }\end{array}$} & $\begin{array}{l}\text { How to best select, adopt and deploy BPM governance frameworks in public sector } \\
\text { settings? }\end{array}$ \\
\cline { 2 - 2 } $\begin{array}{l}\text { How can BPM-related roles and responsibilities be effectively designed and managed in } \\
\text { public sector settings? }\end{array}$ \\
\hline $\begin{array}{l}\text { 13. Strategic Clarity } \\
\text { E Alignment }\end{array}$ & $\begin{array}{l}\text { How can BPM initiatives be best aligned with the strategic directions - especially in } \\
\text { public sector settings? }\end{array}$ \\
\hline \multirow{2}{*}{$\begin{array}{l}\text { 14. External } \\
\text { Environmental } \\
\text { Factors }\end{array}$} & $\begin{array}{l}\text { What contextual factors from the external environment influence BPM initiatives in the } \\
\text { public sector? }\end{array}$ \\
\cline { 2 - 2 } & $\begin{array}{l}\text { How can these external environmental contextual factors influence other critical success } \\
\text { factors within public sector BPM initiatives? }\end{array}$ \\
\hline
\end{tabular}

Table 21: Prospective future research questions

\section{Conclusion}

Governments across the world are still turning to ICT-enabled BPM initiatives to transform their services to citizen-centric and sustainable. A sound understanding of CSFs may provide a firm understanding on areas in need of attention to improve the effective design and implementation of ICT-enabled BPM initiatives. Public sector organisations have different characteristics to those in the private sector and likewise, the developing context is often different to the developed context. This study was driven by the goal to identify and understand CSFs for BPM projects specific to the public sector (in recent research- post the last reported synthesis in 1999), with an anticipation to observe differences between developed and developing contexts.

The paper presents and details CSFs pertaining to BPM initiatives that relate to both the developed and developing country contexts. The analysis confirms and expands prior work on CSFs of public sector BPM, and discusses each factor, providing evidence on the composition of these factors. The paper closes by proposing a set of research questions and areas of investigation for the future as a forming research agenda and making a call for action.

The study is constrained by the lack of literature specific to the public sector BPM initiatives and in particular to papers in developing countries. We acknowledge that this analysis was conducted based on a small pool of papers (31 in total, including 8 from the developing country context).

This paper only focuses on identifying and exploring the critical factors, and does not include testing of the identified CSFs with empirical results. However, the evidence-based CSF synthesis provides opportunities for future research to explore the public sector BPM space to empirically test the validity of the identified factors.

The Fourteen (14) BPM CSFs identified through this inductive analysis of BPM papers from the public sector context yielded factors deemed very similar to BPM CSFs known from generic and/or private sector contexts. While the descriptions of each factor did present contextual specificities associated with the public sector, deeper analysis on how these factors manifest within different sectors (i.e. public vs private) and different institutional contexts would be a useful future investigation. 
The proposed areas of investigation provide direction for areas of future research. We recommend further exploratory research in the context of public sector organisations, in particular the developing country context, to further understand the challenges and opportunities and to validate and respecify the research agenda with stronger evidence-based problematisation as recommended by Alvesson and Sandberg (2013).

\section{References}

Ahmed, I., \& Gregor, S. (2007). A comparative analysis of strategies for egovernment in developing countries. Journal of Business Systems, Governance and Ethics, 2(3), 89-99.

Al-Kibsi, G., de Boer, K., Mourshed, M., \& Rea, N. P. (2001). Putting Citizens On-Line, Not in Line. McKinsey Quarterly, Special Ed(2), 64-73.

Al-Mashari, M., \& Zairi, M. (1999). BPR implementation process: an analysis of key success and failure factors. Business Process Management Journal, 5(1), 87-112. doi:doi:10.1108/14637159910249108

Alghamdi, I. A., Goodwin, R., \& Rampersad, G. (2014). Organizational E-Government Readiness: An Investigation in Saudi Arabia. International Journal of Business and Management, 9(5), 14-24.

Almarabeh, T., \& AbuAli, A. (2010). A general framework for e-government: definition maturity challenges, opportunities, and success. European Journal of Scientific Research, 39(1), 29-42.

Alves, C., Valença, G., \& Santana, A. (2014). Understanding the Factors That Influence the Adoption of BPM in Two Brazilian Public Organizations. In I. Bider, K. Gaaloul, J. Krogstie, S. Nurcan, H. Proper, R. Schmidt, \& P. Soffer (Eds.), Enterprise, Business-Process and Information Systems Modeling (Vol. 175, pp. 272-286). Berlin Heidelberg: Springer

Alvesson, M., \& Sandberg, J. (2013). Constructing Research Questions: Doing Interesting Research. London: SAGE Publications Ltd. Retrieved from http://methods.sagepub.com/book/constructing-research-questions. doi:10.4135/9781446270035

Attaran, M. (2004). Exploring the relationship between information technology and business process reengineering. Information $\mathcal{E}$ Management, 41(5), 585-596.

Axelsson, K., Melin, U., \& Söderström, F. (2011). Analyzing Best Practice And Critical Success Factors in a Health Information System Case - Are There Any Shortcuts to Successful IT Implementation?". Paper presented at the European Conference on Information Systems (ECIS), Helsinki.

Bandara, W., Furtmuller, E., Gorbacheva, E., Miskon, S., \& Beekhuyzen, J. (2015). Achieving Rigour in Literature Reviews: Insights from Qualitative Data Analysis and Tool-support. Communications of the Association for Information Systems. Special Issue on the Literature Review in Information Systems Research.

Bandara, W., Syed, R., Kapurubandra, M., \& Rupasinghe, L. (2012). Building Essential BPM Capabilities to Assist Successful ICT Deployment in the Developing Context: Observations and Recommendations from Sri Lanka. Paper presented at the 5th Annual Workshop of the AIS Special Interest Group for ICT in Global Development, Orlando. http://aisel.aisnet.org/globdev2012/14 
Bazeley, P. (2007). Qualitative data analysis with NVivo. Los Angeles London: SAGE.

Bhatnagar, S. (2004). Building blocks of e-government: lessons from developing countries. World Bank Retrieved from http://www1.worldbank.org/prem/PREMNotes/premnote91.pdf.

Bin Taher, N. A., Krotov, V., \& Silva, L. (2015). A framework for leading change in the UAE public sector. International Journal of Organizational Analysis, 23(3), 348-363. doi:10.1108/IJOA-10-2014-0809

Borman, M., \& Janssen, M. (2012). Critical Success Factors for Shared Services: Results from Two Case Studies. Paper presented at the 45th Hawaii International Conference on System Sciences.

Borras, J. (2012). The OASIS Transformational Government Framework. European Journal of ePractice, 15, 26-51.

Buh, B., Kovačič, A., \& Indihar Štemberger, M. (2015). Critical success factors for different stages of business process management adoption-a case study. Ekonomska istraživanja, 28(1), 243-257.

Chen, Y., Chen, H., Huang, W., \& Ching, R. K. (2006). E-government strategies in developed and developing countries: An implementation framework and case study. Journal of Global Information Management, 14(1), 23.

Chong, S., \& Rosemann, M. (2010). Towards a Framework for BPM Communication. Paper presented at the 7th itAIS Conference Naples

Dada, D. (2006). The failure of e-government in developing countries: A literature review. The Electronic Journal of Information Systems in Developing Countries, 26

Davenport, T. H. (1993). Process innovation: reengineering work through information technology. Boston, Mass: Harvard Business School Press.

Davenport, T. H., \& Short, J. E. (1990). The new industrial engineering: information technology and business process redesign. Sloan Management Review, 31(4), 11-27.

DeCuir-Gunby, J. T., Marshall, P. L., \& McCulloch, A. W. (2011). Developing and Using a Codebook for the Analysis of Interview Data: An Example from a Professional Development Research Project. Field Methods, 23(2), 136-155. doi:10.1177/1525822X10388468

Dexter, B. (2010). Critical success factors for developmental team projects. Team Performance Management, 16(7/8), 343-358. doi:http://dx.doi.org/10.1108/13527591011090637

Dobbins, J. H., \& Donnelly, R. G. (1998). Summary research report on critical success factors in federal government program management. Retrieved from Fort Belvoir, VA:

Doebeli, G., Fisher, R., Gapp, R., \& Sanzogni, L. (2011). Using BPM governance to align systems and practice. Business Process Management Journal, 17(2), 184-202. doi:doi:10.1108/14637151111122310

Dubey, S. K., \& Bansal, S. (2013). Critical Success Factors in Implementing BPR in a Government Manufacturing Unit - An Empirical Study. International Journal of Business and Management, 8(2), 107-124. 
Fettke, P., Zwicker, J., \& Loos, P. (2014). Business Process Maturity in Public Administrations. In J. vom Brocke \& M. Rosemann (Eds.), Handbook on Business Process Management 2 : Strategic Alignment, Governance, People and Culture (Vol. 2;2nd;2nd 2015;). Berlin, Heidelberg: Springer.

Gaffar, A., Deshpande, A., Bandara, W., \& Mathiesen, P. (2015). Importance of literature profiling: An archival analysis with illustrative examples for IS researchers. Paper presented at the PACIS 2015 Proceedings: Pacific Asia Conference on Information Systems.

Gulledge, T. R., \& Sommer, R. A. (2002). Business process management: public sector implications. Business Process Management Journal, 8(4), 364-376. doi:doi:10.1108/14637150210435017

Halachmi, A., \& Bovaird, T. (1997). Process reengineering in the public sector: Learning some private sector lessons. Technovation, 17(5), 227-235. doi:http://dx.doi.org/10.1016/S01664972(96)00123-X

Hartini, A., Francis, A., \& Zairi, M. (2007). Business process reengineering: critical success factors in higher education. Business Process Management Journal, 13(3), 451-469. doi:doi:10.1108/14637150710752344

Heeks, R. (2003). Most eGovernment-for-development projects fail: how can risks be reduced? iGovernment-Information Systems, Technology and Governement: Working Papers.

Heeks, R. (2008a). Benchmarking e-Government: Improving the national and international measurement, evaluation and comparison of e-Government. In Z. Irani \& P. Love (Eds.), Evaluating Information Systems (pp. 257-301). Oxford: Butterworth-Heinemann.

Heeks, R. (2008b). ICT4D 2.0: The Next Phase of Applying ICT for International Development. Computer, 41(6), 26-33. doi:10.1109/MC.2008.192

Heeks, R., \& Stanforth, C. (2007). Understanding e-Government project trajectories from an actor-network perspective. European Journal of Information Systems, 16(2), 165-177.

Hill, J. B., Sinur, J., Flint, D., \& Melenovsky, M. J. (2006). Gartner's position on business process management. Gartner Research G, 136533.

Hisham, M. A., Christopher, G. R., \& Hatem, A. E. K. (2012). Success and Failure of Local EGovernment Projects: Lessons Learned from Egypt Managing E-Government Projects: Concepts, Issues, and Best Practices (pp. 242-261). Hershey, PA, USA: IGI Global.

Hofstede, G. (1984). Cultural dimensions in management and planning. Asia Pacific journal of management, 1(2), 81-99.

Huang, Z., \& Palvia, P. (2001). ERP implementation issues in advanced and developing countries. Business Process Management Journal, 7(3), 276-284.

Hunter, M. G. (2009). Selected readings on strategic information systems (Vol. illustratition). US: IGI Global.

Hutton, G. (1996). Business process re-engineering-a public sector view. In C. Armistead \& P. Rowland (Eds.), Managing Business Processes-BPR and beyond. Chichester: John Wiley and Sons.

International Monetary Fund. (2015). World Economic Outlook :Uneven Growth Short- and LongTerm Factors. Washington, DC. 
Jurisch, M. C., Ikas, C., Palka, W., Wolf, P., \& Krcmar, H. (2012). A Review of Success Factors and Challenges of Public Sector BPR Implementations. Paper presented at the 45th Hawaii International Conference on System Science.

Kamal, M. M. (2006). IT innovation adoption in the government sector: identifying the critical success factors. Journal of Enterprise Information Management, 19(1/2), 192-222.

Kassahun, A. E., \& Molla, A. (2011). BPR Complementary Competence For Developing Economy Public Sector: A Construct And Measurement Instrument. Paper presented at the PACIS.

Kassahun, A. E., Molla, A., \& Sarkar, P. (2011). Government process reengineering: What we know and what we need to know. In C. Susheel \& K. Muneesh (Eds.), Strategic Enterprise Resource Planning Models for E-Government: Applications and Methodologies (pp. 1-24). Hershey PA

Kennedy, A., Joseph, P. C., \& Carol, K. (2012). Business Process Change in E-Government Projects: The Case of the Irish Land Registry Technology Enabled Transformation of the Public Sector: Advances in E-Government (pp. 9-22). Hershey, PA, USA: IGI Global.

Kwamena, S. A. (2012). Improving E-Government Project Management: Best Practices and Critical Success Factors Managing E-Government Projects: Concepts, Issues, and Best Practices (pp. 42-60). Hershey, PA, USA: IGI Global.

Leidecker, J. K., \& Bruno, A. V. (1984). Identifying and using critical success factors. Long Range Planning, 17(1), 23-32. doi:http://dx.doi.org/10.1016/0024-6301(84)90163-8

Likert, R. (1961). New patterns of management.

Marilu, G. (2012). Organizational Change Contributions to E-Government Project Transitions Managing E-Government Projects: Concepts, Issues, and Best Practices (pp. 1-21). Hershey, PA, USA: IGI Global.

Marvine, H., Martin, A. N., Doaa, T., \& Salah, B. (2012). e-Government Implementation in a Developing Country: A Case Study Managing E-Government Projects: Concepts, Issues, and Best Practices (pp. 262-289). Hershey, PA, USA: IGI Global.

McAdam, R., \& Donaghy, J. (1999). Business process re-engineering in the public sector. Business Process Management Journal, 5(1), 33-52. doi:doi:10.1108/14637159910249135

Meier, R., Ben, E. R., \& Schuppan, T. (2013). ICT-enabled public sector organisational transformation: Factors constituting resistance to change. Information Polity: The International Journal of Government \& Democracy in the Information Age, 18(4), 315-329. doi:10.3233/IP-130315

Nfuka, E. N., \& Rusu, L. (2011). The effect of critical success factors on IT governance performance. Industrial Management $\mathcal{E}$ Data Systems, 111(9), 1418-1448. doi:doi:10.1108/02635571111182773

Rainford, S. (2006). e-Sri Lanka: An integrated approach to e-government case study. Regional Development Dialogue, 27(2), 209-218.

Rajapakse, J. (2013). e-Government Adoptions in Developing Countries: A Sri Lankan Case Study. International Journal of Electronic Government Research, 9(4), 38. doi:http://dx.doi.org/10.1108/14637150710823110 
Ravesteyn, P., \& Batenburg, R. (2010). Surveying the critical success factors of BPM-systems implementation. Business Process Management Journal, 16(3), 492-507. doi:doi:10.1108/14637151011049467

Sadowsky, G. (1996). The Internet Society and Developing Countries. e-On The Internet. Retrieved from https://www.isoc.org/oti/articles/1196/sadowsky.html

Streib, G., \& Navarro, I. (2008). City Managers and E-Government Development: Assessing Technology Literacy and Leadership Needs. International Journal of Electronic Government Research, 4(4), 37-53.

Syed, R., Bandara, W., French, E., \& Stewart, G. (2016). The Status of Research on Leadership in Business Process Management: A Call for Action. Paper presented at the ANZAM 2016:30th Australian and New Zealand Academy of Management Conference: Under New Management: Innovating for Sustainable and Just Futures, Brisbane. http://eprints.qut.edu.au/98771/

Tan, W.-G., Cater-Steel, A., \& Toleman, M. (2009). Implementing it service management: A case study focussing on critical success factors. Journal of Computer Information Systems, $50(2), 1$.

Thong, J. Y. L., Yap, C.-S., \& Seah, K.-L. (2000). Business Process Reengineering in the Public Sector: The Case of the Housing Development Board in Singapore. Journal of Management Information Systems, 17(1), 245-270.

Tregear, R., \& Jenkins, T. (2007). Government Process Management: A review of key differences between the public and private sectors and their influence on the achievement of public sector process management. . BPTrends.

Trkman, P. (2010). The critical success factors of business process management. International Journal of Information Management, 30(2), 125-134. doi:10.1016/j.ijinfomgt.2009.07.003

United Nations. (2015). Millennium Development Goals. Retrieved from http://www.un.org/millenniumgoals/

United Nations. (2016). United Nations E-Government Survey 2016: E-Government in Support of Sustainable Development. Retrieved from New York http://workspace.unpan.org/sites/Internet/Documents/UNPAN96407.pdf

Valenca, G., Alves, C. F., Santana, A. F. L., de Oliveira, J. A. P., \& Santos, H. R. M. (2013). Understanding the adoption of BPM governance in Brazilian public sector. Paper presented at the Proceedings of the 21st European Conference on Information Systems.

Walsham, G., Robey, D., \& Sahay, S. (2007). Foreword: Special issue on information systems in developing countries. MIS Quarterly, 317-326.

Walsham, G., \& Sahay, S. (2006). Research on information systems in developing countries: Current landscape and future prospects Ramiro Montealegre was the accepting Associate Editor for this paper. Information Technology for Development, 12(1), 7-24. doi:10.1002/itdj.20020

Ward, J., \& Peppard, J. (2002). Strategic Planning for Information Systems (3rd ed.). West Sussex: John Wiley \& Sons, Ltd. 
Webster, J., \& Watson, R. T. (2002). Analyzing the Past to Prepare for the Future: Writing a Literature Review. MIS Quarterly, 26(2), xiii-xxiii.

Weerakkody, V., Baire, S., \& Choudrie, J. (2006). E-government: the need for effective process management in the public sector. Paper presented at the Proceedings of the 39th Annual Hawaii International Conference on System Sciences, Hawaii.

Weerakkody, V., El-Haddadeh, R., \& Al-Shafi, S. (2011). Exploring the complexities of egovernment implementation and diffusion in a developing country. Journal of Enterprise Information Management, 24(2), 172-196. doi:doi:10.1108/17410391111106293

Weerakkody, V., Janssen, M., \& Dwivedi, Y. K. (2011). Transformational change and business process reengineering (BPR): Lessons from the British and Dutch public sector. Government Information Quarterly, 28(3), 320-328. doi:http://dx.doi.org/10.1016/j.giq.2010.07.010

World Bank. (2014). Implementation Completion and Results Report (ICR-0000939). Retrieved from

Zarei, B., Ghapanchi, A., \& Sattary, B. (2008). Toward national e-government development models for developing countries: A nine-stage model. The International Information $\mathcal{E}$ Library Review, 40(3), 199-207. doi:http://dx.doi.org/10.1016/j.iilr.2008.04.001

Copyright: @ 2018 Syed, Bandara, French \& Stewart. This is an open-access article distributed under the terms of the Creative Commons Attribution-NonCommercial 3.0 Australia License, which permits non-commercial use, distribution, and reproduction in any medium, provided the original author and AJIS are credited.

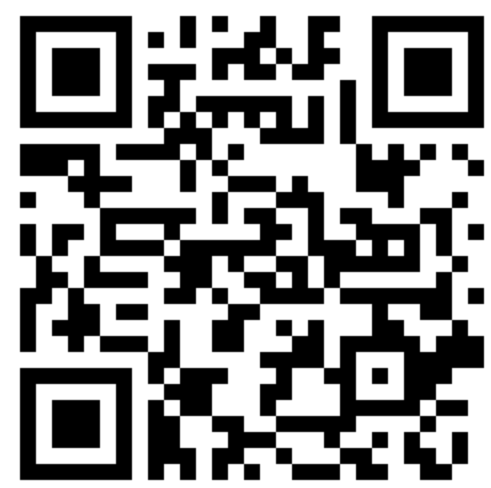

